\title{
Drilling predation traces on recent limpets from northern Patagonia, Argentina
}

\author{
Fernando M. Archuby and Sandra Gordillo
}

\begin{abstract}
In this study we analyze the predator-prey relationship between muricid gastropods (mainly Trophon geversianus) and the limpets Nacella magellanica, Fissurella radiosa, Diodora patagonica and Siphonaria lessoni from recent mollusk death assemblages at Puerto Lobos (4159'54.2" S), on the Atlantic coast of northern Patagonia. The majority of the drill holes fit the ichnospecies Oichnus simplex Bromley, 1981. In five cases the holes resemble Oichnus ovalis Bromley (1983), attributable to octopuses. In analyses of $O$. simplex, the drilling frequency of the whole mollusk assemblage was $4.72 \%$, which is higher than for $N$. magellanica $(3.97 \%)$ and for all limpet specimens together (1.57\%). Drillings were site-selective in the apical sector of the shell, with a notable and statistically significant preference for the U-shaped muscle scar. There is also some evidence of selective predation with respect to size, although the pattern is not strong. The low drilling frequencies on limpets compared to mussels coincide with the general idea that muricid gastropods have a strong preference for sessile prey, due to their inability to handle mobile items. The quantitative incidence of drilling predation on limpets varies considerably between published examples and within the different species of prey studied. The absence of records of drilling predation on fossil limpets remains partially unexplained, except for the fact that limpets are rarely preserved in the fossil record, thus reducing the probability of finding drilled specimens, plus the low frequency in which muricids choose limpet prey for drilling. This is the first study in South America centered on this biotic interaction.
\end{abstract}

Fernando M. Archuby. Instituto de Investigación en Paleobiología y Geología, Universidad Nacional de Río Negro - Consejo Nacional de Investigaciones Científicas y Técnicas (IIPG, UNRN-CONICET), Av. Roca n¹242 (8332) General Roca (Río Negro), Argentina farchuby@gmail.com Sandra Gordillo. Centro de Investigaciones en Ciencias de la Tierra, Consejo Nacional de Investigaciones Científicas y Técnicas - Universidad Nacional de Córdoba (CICTERRA, CONICET-UNC), Avenida Vélez Sarsfield 1611, X5016GCA Córdoba, Argentina gordillosan@yahoo.es

Keywords: Drilling predation; Limpets; Trophon geversianus; Octopuses; Argentine Patagonia, Death assemblages

Archuby, Fernando M. and Gordillo, Sandra. 2018. Drilling predation traces on recent limpets from northern Patagonia, Argentina. Palaeontologia Electronica 21.3.36A 1-23. https://doi.org/10.26879/620

palaeo-electronica.org/content/2018/2246-limpets-predation-in-patagonia

Copyright: September 2018 Palaeontological Association.

This is an open access article distributed under the terms of Attribution-NonCommercial-ShareAlike 4.0 International (CC BY-NC-SA 4.0 ), which permits users to copy and redistribute the material in any medium or format, provided it is not used for commercial purposes and the original author and source are credited, with indications if any changes are made.

creativecommons.org/licenses/by-nc-sa/4.0/ 


\section{INTRODUCTION}

Predator-prey interactions constitute a major ecological process which affects individuals, populations and communities, and links various organisms within and across ecosystems (Kowalewski and Leighton, 2007). Studying predator-prey interactions in deep time also helps evaluate its effect on the diversity, evolution and distribution of a group (Paine, 1966; Vermeij, 1977, 1987; Roy, 1996; Kelley and Hansen, 2003; Leighton and Aronowsky, 2003; Chattopadhyay and Baumiller, 2010; among others). Predator-prey systems involving drilling predation on mollusk shells are especially relevant for paleontologists because the evidence of predation can be analyzed quantitatively. Along the extensive Atlantic coast of Argentine Patagonia, recent shells are naturally concentrated on the beaches by the action of tides, waves and wind. These concentrations are common, and allow a variety of studies centered on the analysis of ecological attributes, such as drilling predation at local or regional level (Gordillo and Archuby, 2012, 2014; Martinelli et al., 2013). The death assemblages constitute appropriate samples of the shelled portion of living communities and are affected mainly by the action of time (Tomašových and Kidwell, 2009, 2010, 2011; Kidwell and Tomašových, 2013; Archuby et al., 2015). The effect of time, i.e., the addition of shells over days, years, centuries or even a few thousand years, creates time-averaged skeletal assemblages that, although lacking time resolution, rules out the biasing effect of short-term sudden changes in species composition and abundance, generated by abiotic or biotic phenomena. An example of this kind of change would be the local extinction of the yellow clam Mesodesma mactroides in the southwestern Atlantic in 1995 (Fiori and Cazzaniga, 1999; Dadon, 2005). These time-averaged samples have been shown to be good proxies of the living communities, from deep marine to continental habitats (Kidwell and Tomašových, 2013). In addition, sampling or experimenting with living marine communities is normally complex and expensive (Warwick and Light, 2002) and does not necessarily guarantee that the results can be extrapolated to the ecosystems (Cleland, 2001). Nevertheless, a possible drawback of using death assemblages as proxies of living communities is the effect of transportation, which might bias species composition and the pat- tern of drill hole features for the sample (Lever et al., 1961; Chattopadhyay et al., 2013a and b).

Previous studies of drilling predation are available, in the form of in situ surveys and/or experiments with living fauna (e.g., Palmer, 1984; 1988; Kabat, 1990; Kowalewski, 2004; Chattopadhyay and Baumiller, 2007; Pio, 2010; Tyler and Schiffbauer, 2012; Gordillo and Archuby, 2012; Archuby and Leighton, 2014), recent death assemblages (Yanes and Tyler, 2009; Martinelli et al., 2013; Gordillo and Archuby, 2014) and fossil assemblages (Taylor et al., 1983; Leighton, 2003; Ceranka and Złotnik, 2003; Klompmaker et al., 2015, and many others). There are also studies, which deal with the temporal patterns of drilling predation (e.g., Kowalewski et al., 1998; Harper, 2003; Kelley and Hansen, 2003; Dietl et al., 2004; Klompmaker and Kelley, 2015, among others). However, there are only a few articles, mostly recent, which provide a quantitative study of drilling predation in death assemblages from southern South America (namely, Gordillo, 1994, 1998; Gordillo and Archuby, 2012, 2014; Martinelli et al., 2013).

In an attempt to characterize the association between muricid drilling intensity and latitude, Martinelli et al. (2013) sampled dead shells along more than $1,000 \mathrm{~km}$ of the Patagonian Atlantic coast (Argentina). The authors found drilling frequencies between 3 and 19\% (with an anomalous figure of 36 in an anthropogenically impacted locality) at the assemblage level, but no correlation with water temperature or latitude. In this study the predator was most probably the muricid Trohpon geversianus. A similar lack of correlation was found for the drilling frequency on the mytilid Brachidontes purpuratus, which was the species with the highest number of drilled specimens (Martinelli et al., 2013). In a survey developed from recent dead shells in Bahía Golondrina, southern Tierra del Fuego (southernmost Argentina), estimated predation frequencies were $16.2 \%$ for Mytilus chilensis and $11.7 \%$ for Aulacomya atra (Gordillo and Archuby, 2012). Visaggi and Kelley (2015) investigated naticid drilling frequency along $4,000 \mathrm{~km}$ of Brazilian coast, and found a significant increase in drilling frequency towards the Equator, which they related with temperature (although other factors might be involved, such as predator diversity and predator-prey size distribution). In a similar study developed in the northern hemisphere, drilling frequency was highest at the mid-latitude in the Caro- 
linian Province (29 to $34^{\circ} \mathrm{N}$; Kelley and Hansen, 2007). Drilling predation on grazing gastropods such as limpets from the shallow rocky shores of Patagonia is interesting for biologists because of the ecological role that the consumers play in regulating community structure (Bazterrica et al., 2007; Adami, 2008). The study of drilling predation on limpets has attracted little attention, as shown by the scarce literature available, despite the fact that limpets and drilling predators are major components of rocky shallow marine environments everywhere (Black, 1978; Palmer, 1980, 1984, 1988; Visaggi and Kelley, 2007; Yanes and Tyler, 2009; Yamamoto, 1993, 2004; Chim and Ong, 2012; Martinelli et al., 2013). The few previously published studies centered on this biotic interaction are limited to isolated cases which provide field observations and/or laboratory experiments. This study characterizes the predator-prey relationship between drilling predators and the limpets sensu lato (i.e., Nacella magellanica Gmelin, Fissurella radiosa Lesson, Diodora patagonica d'Orbigny and Siphonaria lessoni Blainville) from recent mollusk assemblages at Puerto Lobos, in northern Patagonia. Previous studies suggest that these limpet species are not particularly chosen as prey (e.g., Martinelli et al., 2013). The most abundant drilling predators in this area are muricid gastropods, which, unlike naticid species, do not handle their prey but instead crawl over it in order to find a place to drill and to proceed with predation (Carriker and Van Zandt, 1972; Pio, 2010; Martinelli et al., 2013). There is little known about the pattern of predatory drill holes left on limpet shells, but some mentions can be found in Palmer (1988), Visaggi and Kelley (2007) and Yanes and Tyler (2009). So far, no relevant studies in Patagonia have been published, and there is an absence of theoretical explanations of this predatory behavior. We therefore propose that 1) drilling frequencies are lower for limpets than for the sessile and more abundant epifaunal species such as mytilids; 2) as shown in studies of other prey species, stereotyped behavior occurs (in drilling place selection). This selection of a drilling site is evidence of the biotic origin of the trace and provides important information concerning the nature of the interaction (Kowalewski, 2002); 3) there is size selection which (potentially) maximizes the energy gain of the predatory activity. We also expect differences in the intensity of predation due to intrinsic features of the species (e.g., behavior); and 4) drilling predators consume limpets regularly, and the absence of traces of this interaction in the fossil record is due to a taphonomic bias.

\section{The Potential Drilling Predators}

Trophon geversianus Pallas is the most common predator sea snail inhabiting both rocky and soft shallow bottoms along the Argentine Patagonian coast. Its area of distribution extends along the Atlantic coast from Buenos Aires province to Tierra del Fuego and along the Pacific coast of Chile to at least the Chonos Archipelago (Griffin and Pastorino, 2005). In southern Patagonia, this muricid gastropod mainly preys upon mytilids and venerid clams (Gordillo, 1994, 1998; Andrade and Ríos, 2007; Gordillo and Archuby, 2012, 2014), depending on the predominant prey available in the habitat in which it lives. In a similar way to other muricids, $T$. geversianus drills its prey by alternating between mechanical and chemical methods. Pio (2010) identified and described the accessory boring organ $(A B O)$ anatomically through studies of the histology of the organ and the glands related with boring activity. After field and laboratory surveys, the author concluded that this gastropod bores the shell by alternating between the application of the $A B O$, the secretions from the glands related to the propodial groove and rasping by the radula. Complete holes on mollusk shells drilled by T. geversianus vary from cylindrical to conical and can be located in different parts of the shell, depending on the prey species drilled (Gordillo, 1994, 1998; Gordillo and Archuby, 2012). Holes made by $T$. geversianus correspond to the ichnospecies Oichnus simplex Bromley (1981) although certain variations in the shape of the walls of these holes might cause them to be misidentified as 0 . paraboloides (made by naticids), whose walls have a parabolic outline (Bromley, 1981). Another diagnostic feature which is useful for recognizing holes made by muricids (and for differentiating them from holes made by naticids) is that incomplete holes have a concave or flat bottom, surrounded by a circular edge (Gordillo and Archuby, 2012, 2014) and micro-rasping marks made by the radula, which can be observed under a scanning electron microscope (Schiffbauer et al., 2008; Tyler and Schiffbauer, 2012). A third indirect criterion for recognizing a predator snail is to consider the presence/absence or relative abundance of potential predators for each mollusk assemblage under study. Martinelli et al. (2013) carried out an extensive study along most of the Atlantic Patagonian coast and showed that drilling predator species other than $T$. geversianus are very rare, and they 
concluded that most of the drilled shells were preyed upon by this muricid species. The authors reported that, out of 422 potential drilling predator specimens, 405 (96\%) were T. geversianus, and the remaining species were the muricid $T$. plicatus (6 specimens, 1.5\%) and the naticid Notocochlis isabellana (11 specimens, 2.5\%). T. geversianus, as evidenced by some previous studies, is a generalist species that mainly feeds on filter feeder bivalves, both mussels and clams (Gordillo, 1998; Gordillo and Archuby, 2012, 2014; Martinelli et al., 2013). In addition, during times of reduced food supply, it appears that this species is also able to drill conspecifics (Gordillo, 2013).

The oval holes, Oichnus ovalis Bromley, attributed to octopuses, can be produced by the small, intertidal/shallow subtidal octopuses Octopus tehuelchus d'Orbigny or Robsonella fontaniana d'Orbigny, which inhabit the area studied and have been identified at Puerto Lobos (Ré, 1989). Octopus tehuelchus is a small sized intertidal and shallow subtidal species found in the southwestern Atlantic from southern Brazil $\left(30^{\circ} \mathrm{S}\right)$ to the northern Argentine Patagonia (from $43^{\circ}$ to $44^{\circ} \mathrm{S}$ ) (Iribarne, 1991; Iribarne et al. 1991). Iribarne et al. (1993), observed under laboratory conditions that this species drilled Tegula patagonica shells used as shelter by the hermit crab Pagurus sp. Robsonella fontaniana is a small-sized octopus distributed from northern Peru in the Pacific Ocean up to Puerto Lobos in northern Argentine Patagonia. This species inhabits from the intertidal to 225 meters deep, prefers hard bottoms, and is uncommon (Ibáñez et al., 2008, 2009). $R$. fontaniana is a highly selective predator that consumes crabs and other decapods and, in experimental conditions, did not consume gastropods but only decapods (Ibáñez, et al., 2009). Drill holes made by octopods are placed in the ichnospecies Oichnus ovalis Bromley, 1993. The incidence of O. ovalis is quantitatively minor but easily identifiable. These holes are elongated with an oval, rather than circular, outer border. The walls of this drill hole have a scooped or beveled appearance, and the inner hole is smaller than the outer one, and is sometimes rather ragged. Many of the drill holes have a prominent gutter that extends from the hole along its long axis (Bromley, 1993; Harper, 2002).

\section{Limpets: The Prey}

Limpets are snails with a cup-shaped shell instead of a coiled one. They use a large, flat foot to tightly clamp the rock. As limpets sensu lato, we include true limpets, key-hole limpets and pulmon- ate limpets, which represent a nonmonophyletic group. They are very common sedentary herbivore grazers in the rocky intertidal zone of the Atlantic coast of Argentina. In Argentine Patagonia, besides the aforementioned carnivorous gastropod T. geversianus, other potential predators of limpets reported include oystercatchers (Haematopus palliatus, Haematopus ater), kelp gulls, (Larus dominicanus), fishes (Patagonotothen cornucola, Helcogrammoides cunninghami), seastars (Anasterias minuta) and crabs (Cyrtograpsus altimanus, Cyrtograpsus angulatus, Carcinus maenas) (Lowell, 1986; Pacheco and Castilla, 2001; Daleo et al., 2005; Bazterrica et al., 2007; Hidalgo et al., 2007; Gil and Zaixso, 2008; Woods, 2014). Limpets as prey present different challenges to potential predators, including mobility, preferred depth, palatability, shell size, etc. (McQuaid et al., 1999; Rovirosa and San Martín, 2006; Laitano et al., 2008; Yanes and Tyler, 2009; Tyler et al., 2014).

The true limpet Nacella magellanica Gmelin is widely distributed throughout Patagonia, extending from Puerto Montt on the Pacific $\left(42^{\circ} \mathrm{S}\right)$ to the Buenos Aires Province on the Atlantic $\left(35^{\circ}-40^{\circ} \mathrm{S}\right)$, and including the Strait of Magellan, Cape Horn, Tierra del Fuego and the Malvinas Islands (Powell, 1973; Valdovinos and Ruth, 2005; GonzálezWevar et al., 2012). This species is the most abundant and conspicuous limpet and has a narrow bathymetric range circumscribed within the intertidal and shallow subtidal areas of Patagonia (Morriconi, 1999; González-Wevar et al., 2012). A phylogeographic study of this species in the Atlantic Patagonia identified a very recent geographic demographic expansion at ca. 11,000 years BP (De Aranzamendi et al., 2011).

The key-hole limpet Fissurella radiosa Lesson is distributed along the Pacific from the Gulf of Corcovado, east of the island of Chiloé $\left(42^{\circ} 42^{\prime} \mathrm{S}\right)$ to Tierra del Fuego $\left(55^{\circ} \mathrm{S}\right)$, and along the Atlantic from the north of Argentina down toward the San Matías Gulf. At $42^{\circ} \mathrm{S}$, the subspecies F. radiosa tixierae is typical (Mc Lean, 1984; Olivares Paz, 2007). This species occupies the intertidal and tide pools up to $20 \mathrm{~m}$ deep (Mc Lean, 1984), and is of more recent origin, compared to other species of Fissurella in the south eastern Pacific (Olivares Paz, 2007; Olivares Paz et al., 2011).

A second key-hole limpet, Diodora patagonica (d'Orbigny), extends from southern Brazil to northern Argentine Patagonia. This subtidal species inhabits rock crevices at depths of less than $30 \mathrm{~m}$ (Scarabino, 1984). The fossil record of this species 
can be traced to the Pleistocene (Lopes and Simone, 2012).

Finally, the pulmonate limpet Siphonaria lessoni Blainville has a very wide area of distribution along the Atlantic, from southern Brazil to Tierra del Fuego, and along the Pacific up to $18^{\circ} \mathrm{S}$. This is an intertidal species which lives on rocky coasts, feeding on algae and bacteria (Tablado and Gappa, 2001; Adami, 2008). Nuñez et al. (2012) showed that the expansion of this species is associated with environmental changes occurring during the Pleistocene glacial cycles, and they estimated a divergence between the Pacific and the Atlantic populations in 1,000,000-100,000 ys BP.

\section{MATERIAL AND METHODS}

Samples were taken in April, 2010, from mollusk death assemblages along the Puerto Lobos beach $\left(41^{\circ} 59^{\prime} 54.2\right.$ " S; Figure 1), close to the high water mark level (Figure 2.1). Puerto Lobos is located in the Chubut province, on the southern part of the San Matías Gulf, almost on the limit with the province of Río Negro. It consists of beaches with sand, small pebbles and gravel, and rocky areas characterized by different types of habitat, including pools, cobbles, boulders, crevices and platforms (Gelós et al., 1994; Yorio et al., 1998). The death assemblages, formed from the supply of shells from strandings caused by storms, currents (López et al., 2008) and wind, are considered to be good proxies of the intertidal communities they inhabit (Archuby et al., 2015).

Two bulk samples were collected. The first one, the death assemblage sample (DAS), consisted of the entire set of mollusk shells taken from 20 randomly placed $0.5 \times 0.5 \mathrm{~m}$ quadrats (Figure 2.2). This sample was used to establish the quantitative relevance of drilling predation by means of

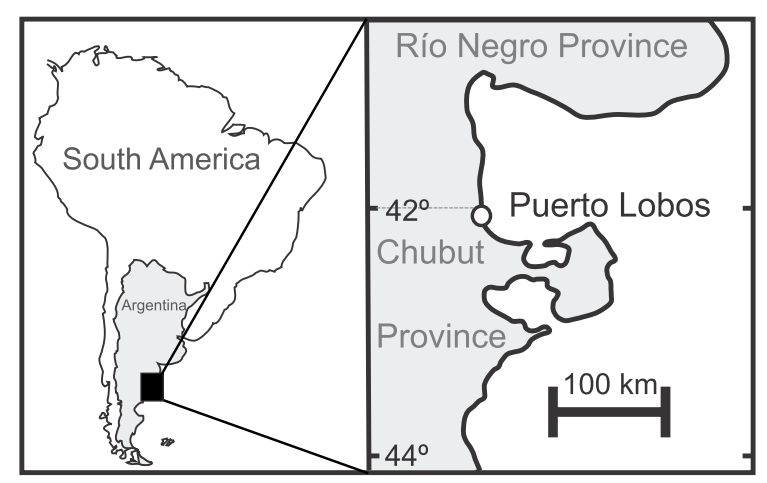

FIGURE 1. Location map of Puerto Lobos in the southern part of the San Matías Gulf, Patagonia, Argentina. the sample and per-species predation rates (number of drilled individuals/[number of drilled + undrilled individuals]). As it is based on a bulk sample of the assemblage, it is comparable with other examples. It is also useful for assessing the presence of potential drilling predators. In order to characterize the mollusk assemblage, all recognizable shells were considered. The second sample consisted exclusively of limpet shells ('limpet sample' or LS) and was collected from the same beach, contiguous to a boulder field, with the goal of increasing the number of limpets for the quantitative analyses (Figure 2.3). Only well-preserved shells (complete or with minor damage) were counted and examined for traces of drilling predation.

Every shell from the limpet sample was carefully examined with the help of a hand lens and microscope in the search for predatory drillings (Figure 3.1). Drillings were photographed with a digital camera mounted on a binocular lens (Nikon SMZ-800, with a 3.2 Mp AccuScope mounted camera). Some holes were photographed with a scanning electron microscope (Zeiss, Evo MA15). All regularly shaped, rounded and oval holes perpendicular to the shell surface were considered as predatory and assigned to the bioerosive trace Oichnus Bromley, following Bromley (1981, 1993). Shells with drillings were measured (anterior-posterior length, or APL) with digital calipers to the nearest $0.01 \mathrm{~mm}$. To compare the size of drilled and undrilled limpets, the APL of a sample of nondrilled specimens $(n=59)$ was also measured. In order to characterize the morphology of the holes and to evaluate the correlation between prey size and hole size, minimum and maximum inner drill hole diameters were measured with a scale incorporated to the binocular lens. In the case of $O$. simplex we considered the minimum inner diameter to be the best proxy for the diameter of a predator's proboscis, and this measurement was therefore used as a proxy for predator size (Kabat, 1990, and references cited therein).

Drilling frequency (DF) was considered as a measure of how often organisms are attacked by drilling predators, and so includes incomplete drillings. However, we are aware of the fact that DF often underestimates the predation of gastropods since it has been shown that, depending on the prey species and size and the predator species, a successful predation often leaves no trace, or incomplete holes (Palmer, 1980; Palmer, 1984; Gordillo and Archuby, 2012; Archuby and Leighton, 2014). DF was calculated by dividing the total num- 


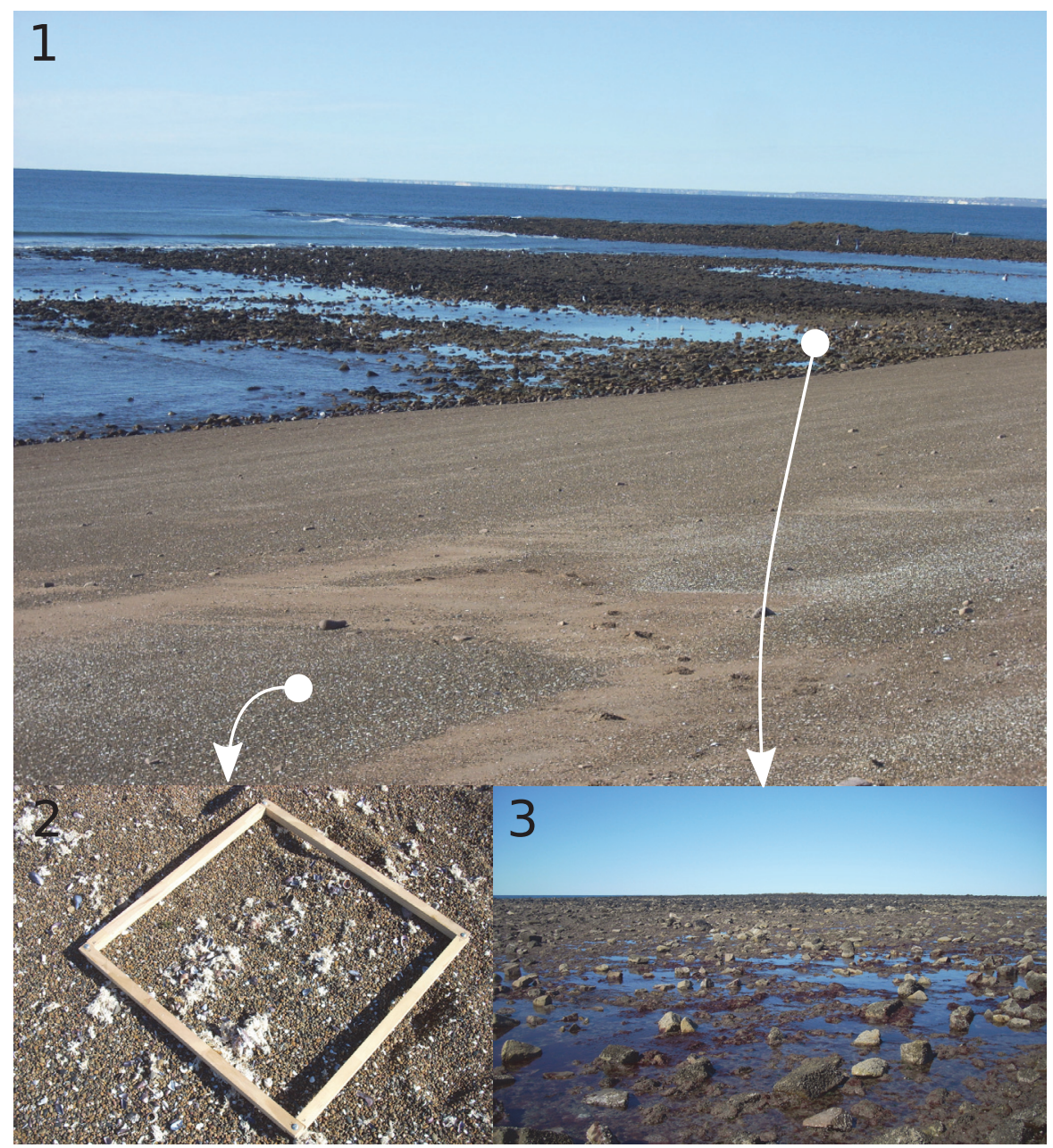

FIGURE 2. Sampling: (1) view of the modern beach of Puerto Lobos showing a boulder field at low tide (distance from the boulder to the steps is approximately $15 \mathrm{~m}$ ). (2) detail of the $50 \times 50 \mathrm{~cm}$ quadrate used for sampling mollusk specimens. (3) Detail of the boulder field (from side to side the picture measures ca. $5 \mathrm{~m}$ ).

ber of drilled shells by the total number of individuals examined, and multiplied by 100 (i.e., 100* specimens drilled/sample size). In the case of disarticulated bivalves, the number of valves with drill holes was divided by half the total number of valves examined. The DF was calculated from the DAS. Another way of quantitatively estimating the incidence of drilling predation adopted in this study is the percentage that corresponds to each taxa if only drilled specimens from the DAS or LS are considered.

Quantitative analyses were restricted to shells with O. simplex in N. magellanica. To test whether drillings are preferentially placed in particular size classes of prey shells, we developed two strategies. The size (anterior-posterior length or APL) of well-preserved drilled $N$. magellanica specimens $(n=36)$ were compared with sizes of a random sample of non-drilled shells of the same species ( $n$
= 59) by means of an independent two-sample ttest for equal variances ( $F$-test, $p=0.869$ ) and a Kolmogorov-Smirnov test. Although both samples fitted the normal distribution, the presence of outliers also justified trying the rank-based non parametric Wilcoxon test for two independent samples. The Pearson and Spearman rank correlation coefficients were calculated between the APL and the minimum inner hole diameters.

To understand any preferential selection of drill site, three analyses were considered: the first one compared the anterior versus the posterior halves (analysis 1); the second one compared the upper (sector 1), middle (U-shaped muscle scar or sector 2) and lower (sector 3 ) sectors (analysis 2); and the third used muscle scar band versus the rest of the shell (analysis 3 ). In all three cases we assumed that the predator does not choose the place to drill (i.e., every point has the same proba- 


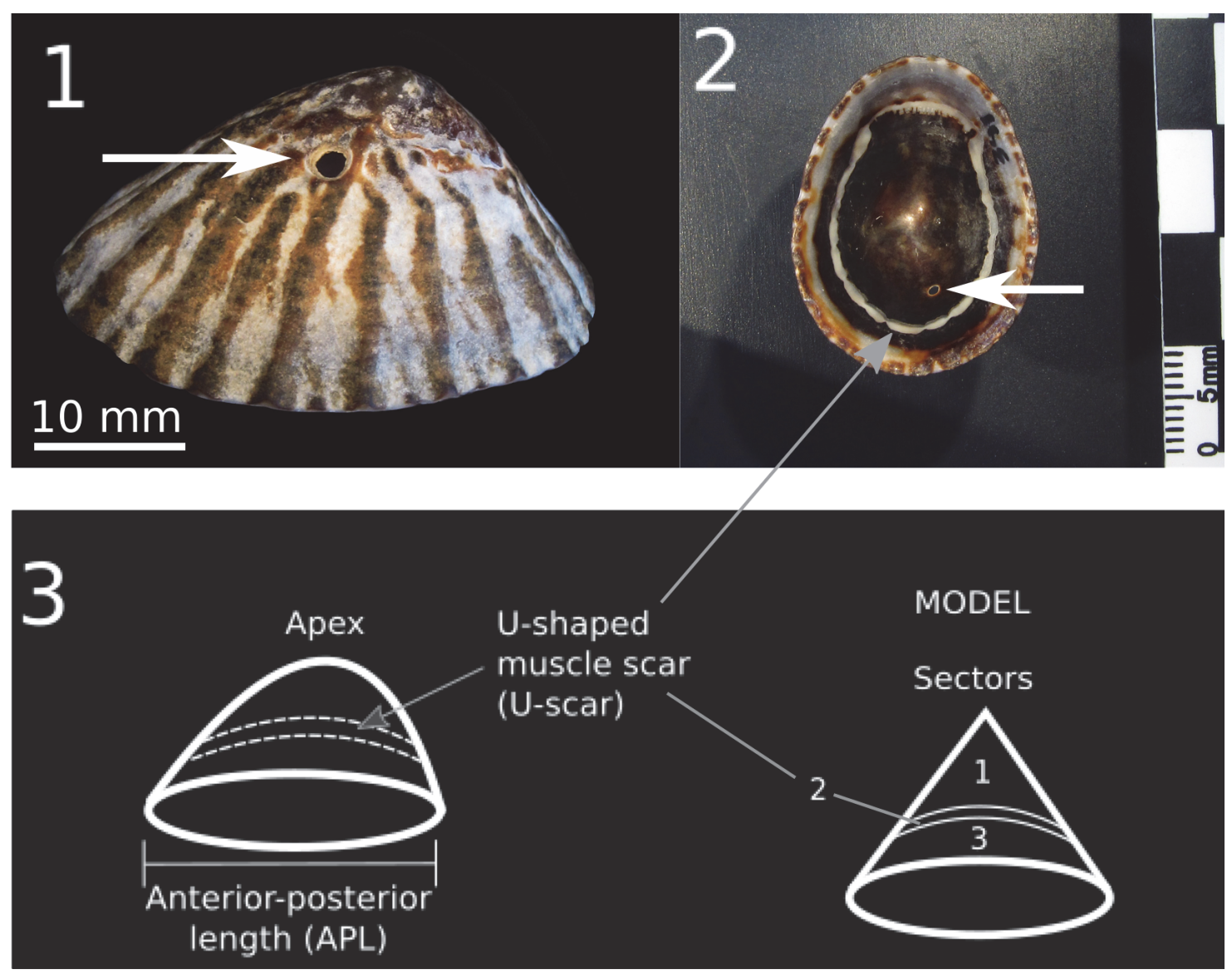

FIGURE 3. (1). External view of a specimen of Nacella magellanica with a drilling on the posterior part (CEGH-UNC26872). (2). Internal view of a specimen of Nacella magellanica with a drilling on the posterior part, above the Ushaped muscle scar (CEGH-UNC-26873). (3). Modeling of limpet shell as cone and truncated cones to estimate the proportion of the area represented by the different sectors. To the left, a real representation of a limpet shell. The $U$ shaped muscle scar (U-scar) is visible from the inside. To the right, the model composed of one cone and two truncated cones.

bility of being drilled). We estimated the expected frequencies according to the proportion of area represented by each sector, and then we compared the observed and the expected frequencies using a chi-square goodness of fit test (Zar, 2010). Prey-species preference for drilling was assessed with a contingency table (Zar, 2010).

For analysis 1 we divided the shell into anterior and posterior halves (anterior or posterior to the apex, respectively) in order to test whether the predator prefers to attack one end of the limpet. We assumed that the anterior and posterior halves have equal areas. Analyses 2 and 3 were performed in order to look for preference of attack in a dorso-ventral direction. In the first approach (analysis 2), the limpet shell was divided into three areas associated with the U-shaped muscle scar, or Uscar. The U-scar is left by the attachment of the foot retractor muscles present on the sides and in the rear part of the shell. The U-scar continues towards the anterior part of the shell with the scar left by the attachment of the mantle (Figure 3.2). The three sectors of analysis 2 are therefore (1) the upper (apical) area, located above the Ushaped muscle scar; (2) the middle area, corresponding to the U-shaped muscle scar; and (3) the lower (basal) area, from the U-shaped muscle scar to the margin of the shell (Figure 3.3). In the second approach (analysis 3) we tested for a preference for the muscle scar band versus the rest of the shell. We had previously observed that shells usually lose the outer layer from the band to the apex, suggesting the presence of a weaker zone in the shell, and perhaps a place where chemicals from the prey cross the shell and can be detected by the predator. The expected frequencies of the three sectors were calculated as sample size multiplied by the proportion of the area of the shells in 
each sector. To estimate this proportion, we modeled the sectors as cones (upper) and truncated cones (middle or muscle band and lower). We estimated the areas for 31 specimens, calculated the percentages per specimen and averaged the percentages per sector for the whole sample.

The material is housed in the collection of the Centro de Investigaciones en Ciencias de la Tierra (Consejo Nacional de Investigaciones Científicas y Técnicas and Universidad Nacional de Córdoba). Statistical analyses and plots were carried out using R (R Core Team, 2014) and PAST (Hammer et al., 2001).

\section{RESULTS}

\section{Faunal Composition of Mollusk Assemblages}

The mollusk assemblage $(n=2990)$ taken from Puerto Lobos beach was composed of 26 species (15 gastropods and 11 bivalves). The database of the mollusk assemblage is available in Appendix 1. Of 1042 gastropods, 445 were limpets: Nacella magellanica (126), Diodora patagonica (3), Fissurella radiosa (74) and Siphonaria lessoni (242), and 275 were potential drilling predators: the muricid Trophon geversianus (271) and the naticid Notocochlis isabelleana (4).

\section{Drill Hole Morphology}

Two different kinds of holes were found, both of which run perpendicular to the shell surface. The majority open to the interior of the animal where the soft parts were placed, and the diameter reduces from the outside to the inside. In general, we found one hole per valve (Figure 4.1). Two exceptions were found in the limpet sample, and in both one hole is incomplete or non-functional (Figures 4.2 and 5.2). In the first kind of hole, complete predatory drill holes exhibit circular to subcircular external outlines with straight walls (Figures 4.1 and 5.1), while incomplete holes have flat bottoms surrounded by a circular edge (Figures 4.2 and 5.4), fitting comfortably into the ichnospecies Oichnus simplex Bromley, 1981 (holes characteristically made by muricid gastropods). Marks of micro-rasping by multiple elements compatible with the action of radula teeth (like Radulichnus isp.) were detected in images taken with the scanning electron microscope (Figure 5.4-6). The second type of hole, O. ovalis Bromley, was found in four specimens (Figures 4.3-4, 5.3). Coinciding with Bromley's (1993) description of this bioerosion, the holes studied here are characterized as oval shaped, tapering subparabolically, with a minute internal aperture and an external aperture which usually has an oval to rhomboid outline. This ichnospecies is associated with the predatory activity of octopuses. All five O. ovalis were found on Nacella magellanica shells.

\section{Drilling Frequencies and Species Selection (only Oichnus simplex on Nacella magellanica)}

Of 26 mollusk species recovered from the sample of the mollusk assemblage, 7 species ( 3 gastropods, 4 bivalves) contained drilled specimens (Table 1). Of the 141 drilled specimens, only $9(6.38 \%)$ were gastropods, including limpets, and $132(93.62 \%)$ were bivalves, all of them Mytilidae. The drilling frequency for the whole assemblage reached $4.72 \%$. Drilling frequency of the pooled sample of limpets is $1.57 \%$ while for Nacella magellanica it is higher, $3.97 \%$. Limpets represent $4.96 \%$ of the total bored shells. A contingency table applied to drilled species of the DAS, classifying taxa as 'limpets', 'Mytilids' and 'Tegula patagonica', and specimens as 'drilled' and 'undrilled', showed that neither classification is independent $\left(X^{2}=26.05 ; \quad p<0.000\right)$, i.e., the drilling predator selected some species more frequently than others. Two specimens of $T$. patagonica were found drilled. The high mobility of this species and the position of the holes, placed in the last whorl, close to the umbilicus and the aperture, suggest that the holes might not have been produced by muricids, although this speculation requires more research.

Of 709 well-preserved limpet shells from the limpet sample (excluding those with $O$. ovalis), 40 $(5.64 \%)$ had drill holes assigned to 0 . simplex; 38 $(95 \%)$ of these drillings were found on Nacella magellanica and only two (5\%) on Siphonaria lessoni (Table 2). Drilling frequency for $N$. magellanica is $8.48 \%(100 * 38 / 448)$, which is higher than the estimation for the DA sample. No drillings were detected on Fissurella radiosa or Diodora patagonica shells. The abundance of drill holes depends on the species (contingency table, $X^{2}=18.34$, $\mathrm{p}<0.000$ ), with $N$. magellanica significantly more drilled than expected (i.e., there is evidence of prey selection by the predator). Four specimens of $N$. magellanica had octopus-like holes (O. ovalis). Only two specimens of $N$. magellanica had two holes, while all the rest had one or none. One example is illustrated in Figure 5.1-2, in which the limpet has two $O$. simplex holes (complete and functional, and incomplete, respectively). The other case corresponds to a limpet with two $O$. ovalis holes, one complete and functional (Figure 5.3) and the second incomplete. In the next sections we 

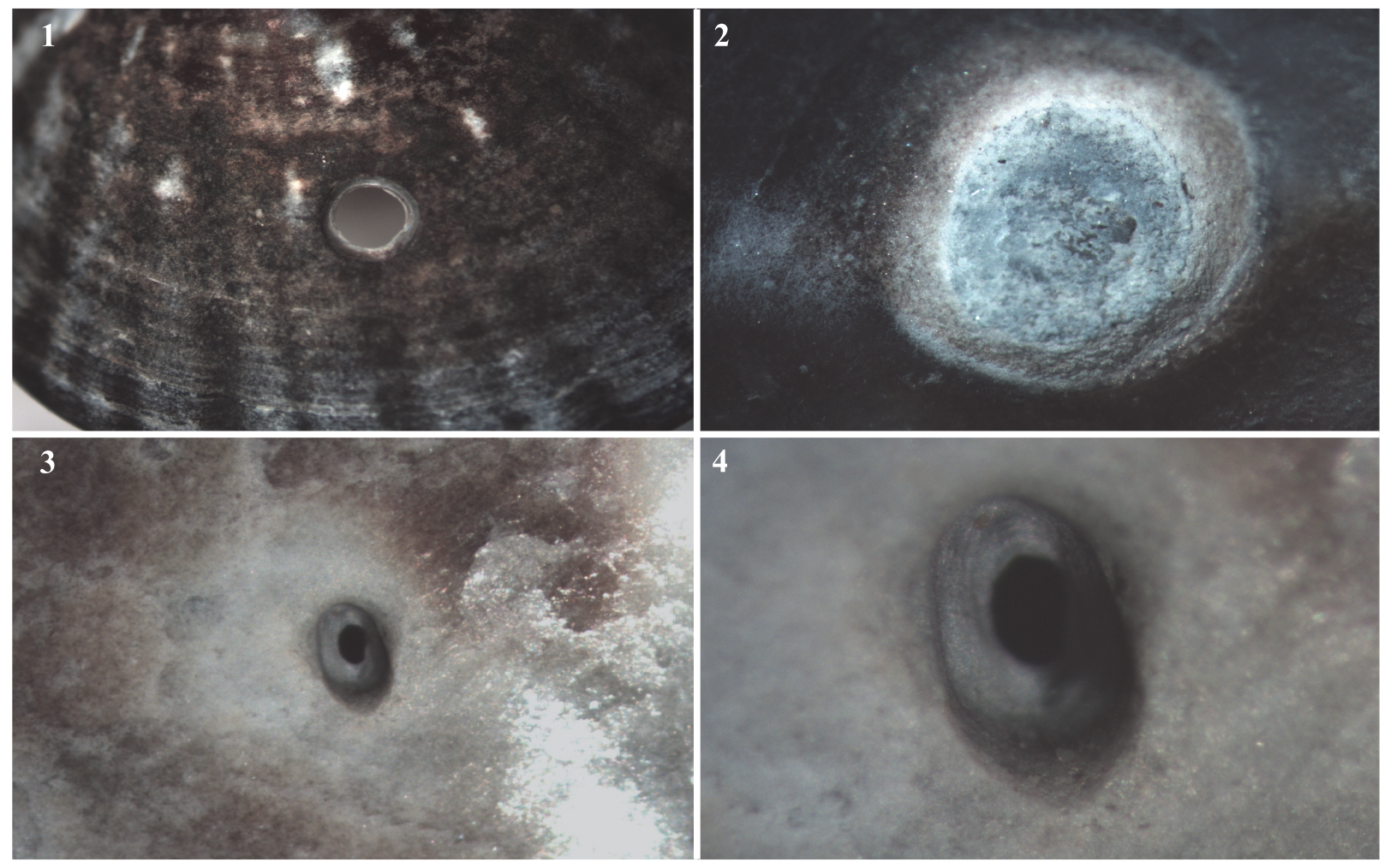

FIGURE 4. Photographs of drill holes. (1) Successful muricid drill hole (Oichnus simplex) (internal minimum diameter of the hole: $1.76 \mathrm{~mm}$; CEGH-UNC-26874). (2) Unsuccessful muricid drill hole (external minimum diameter of the hole: $1.75 \mathrm{~mm}$; CEGH-UNC-26875). (3 and 4), Octopus drill hole (Oichnus ovalis) (internal minimum and maximum diameters of the hole: 0.15 and $0.27 \mathrm{~mm}$, respectively. Both images correspond to the same specimen, CEGH-UNC26876).

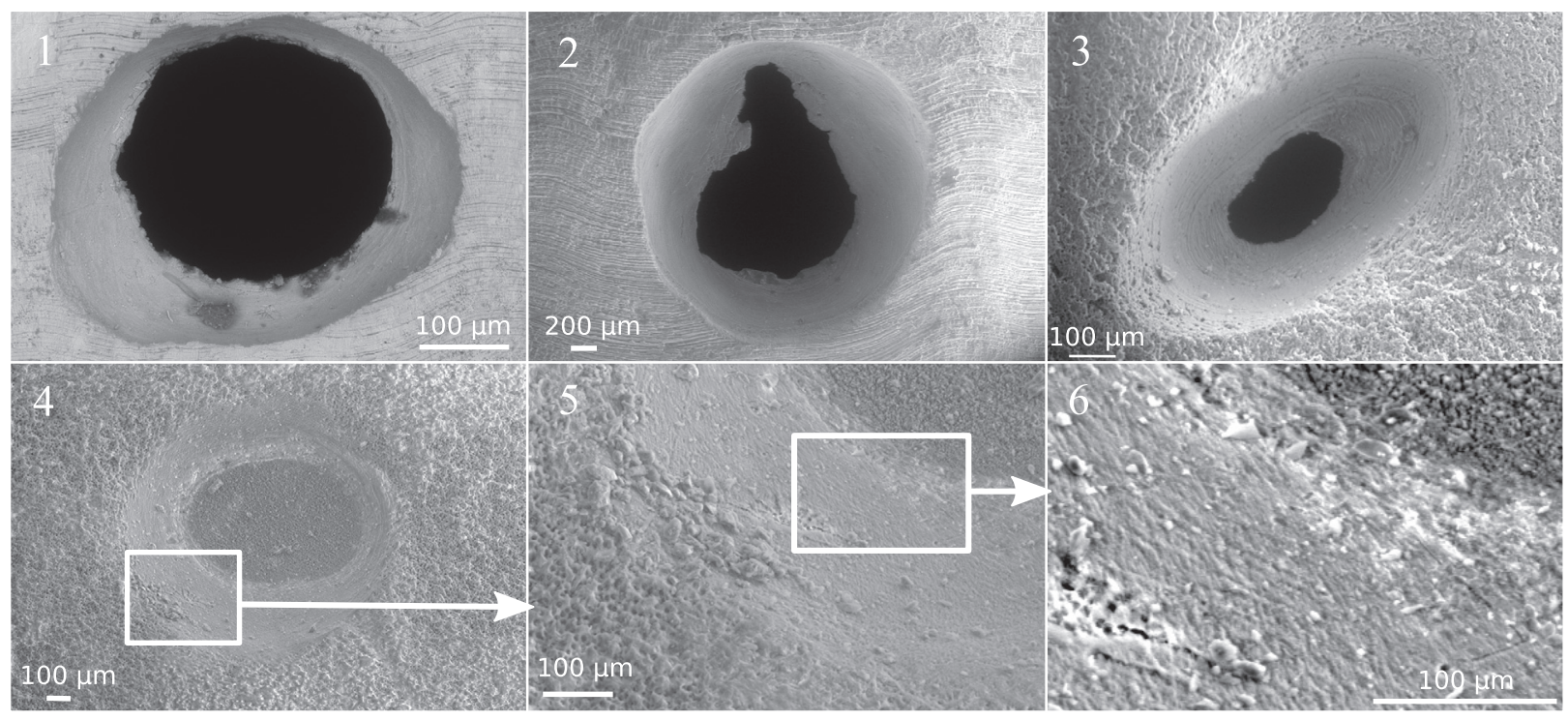

FIGURE 5. Scanning electron microscope images of drill holes on Nacella magellanica shells. (1). Complete and functional Oichnus simplex (CEGH-UNC-26877). (2). Complete non-functional O. simplex (CEGH-UNC-26877). 3. Complete and functional Oichnus ovalis (CEGH-UNC-26876). (4-6). Incomplete O. simplex. (4). Note the flat nature of the bottom. (5) and (6) magnifications of a drill hole wall with probable radular rasp marks. (4-6, CEGH-UNC26878). 
TABLE 1. List of drilled species recovered from Puerto Lobos beach. Bulk sample of the death assemblage.

\begin{tabular}{llccc}
\hline \multicolumn{1}{c}{ Families } & \multicolumn{1}{c}{ Species } & Total shells & Drilled shells & $\begin{array}{c}\text { Drilling } \\
\text { frequency }\end{array}$ \\
\hline Fissurellidae & Fissurella radiosa & 74 & 0 & 0 \\
Fissurellidae & Diodora patagonica & 3 & 0 & 0 \\
Patellidae & Nacella magellanica & 126 & 5 & 3.97 \\
Trochidae & Tegula patagonica & 241 & 2 & 0.83 \\
Siphonariidae & Siphonaria lessoni & 242 & 2 & 0.83 \\
Mytilidae & Mytilus platensis & 197 & 18 & 9.14 \\
Mytilidae & Brachidontes rodriguezi & 437 & 46 & 10.53 \\
Mytilidae & Brachidontes purpuratus & 1,160 & 47 & 4.05 \\
Mytilidae & Aulacomya atra & 119 & 21 & 17.65 \\
\hline
\end{tabular}

TABLE 2. Predator preferences between limpet species. Data obtained from the limpet sample.

\begin{tabular}{lccc}
\hline \multicolumn{1}{c}{ Species } & Nacella magellanica & Fissurella radiosa & Siphonaria lessoni \\
\hline Total shells & 448 & 67 & 194 \\
$\mathrm{n}$ & 63.19 & 9.45 & 27.36 \\
$\%$ & & & \\
Drilled shells & 38 & 0 & 2 \\
$\mathrm{n}$ & 95 & 0 & 5 \\
$\%$ & & & \\
Drilling frequency per species & 8.48 & 0 & 1.03 \\
\hline
\end{tabular}

will quantitatively analyze only 0 . simplex. In Appendix 2 the information of drilled specimens of the limpet sample is provided.

\section{Size Selectivity}

The size of drilled specimens of $N$. magellanica $(n=36)$ does not differ statistically from a random sample of undrilled ones $(n=59)$ : the median and mean of drilled shells are not significantly different from the median and mean of the undrilled (Wilcoxon sum ranks test, $p=0.284$; t-test, $p=$ 0.179; Figure 6). Distributions are not significantly different from each other (Kolmogorov-Smirnov test, $p=0.492$ ).

The drill-hole maximum inner diameter on Nacella magellanica limpets averages $2.047 \mathrm{~mm}$ (95\% confidence limits with bootstrap, $n=9,999$, 1.913 to $2.185 \mathrm{~mm}$ ). The minimum internal diameter averages $1.832 \mathrm{~mm}$ (95\% confidence limits with bootstrap, $n=9,999,1.693$ to $1.964 \mathrm{~mm}$ ). There is a moderate significant positive correlation between shell size and drill hole size (minimum internal diameter) (Pearson $r=0.389$; $p=0.021$; Spearman

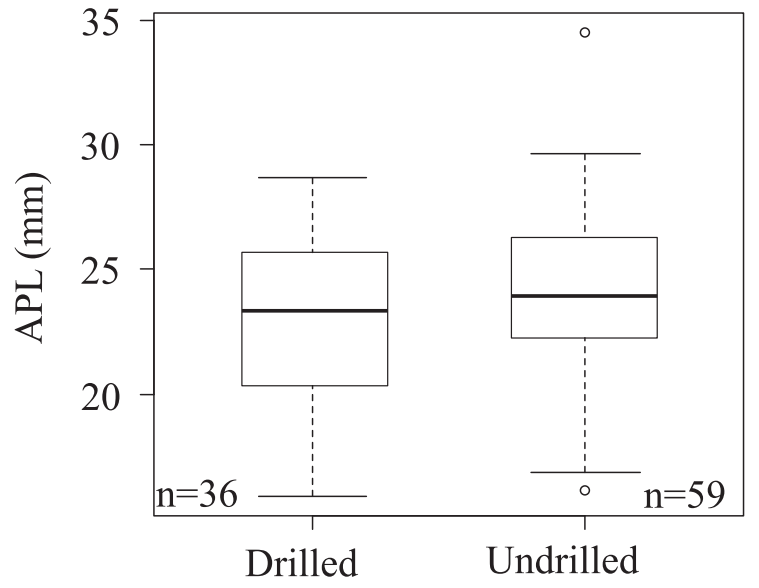

FIGURE 6. Box plot of anterior-posterior length (APL) of drilled $(n=36)$ and undrilled $(n=59)$ Nacella magellanica shells. Undrilled shells are slightly larger although non significantly different from drilled ones (Wilcoxon sum ranks test, $p=0.284$; t-test, $p=0.179$ ). 


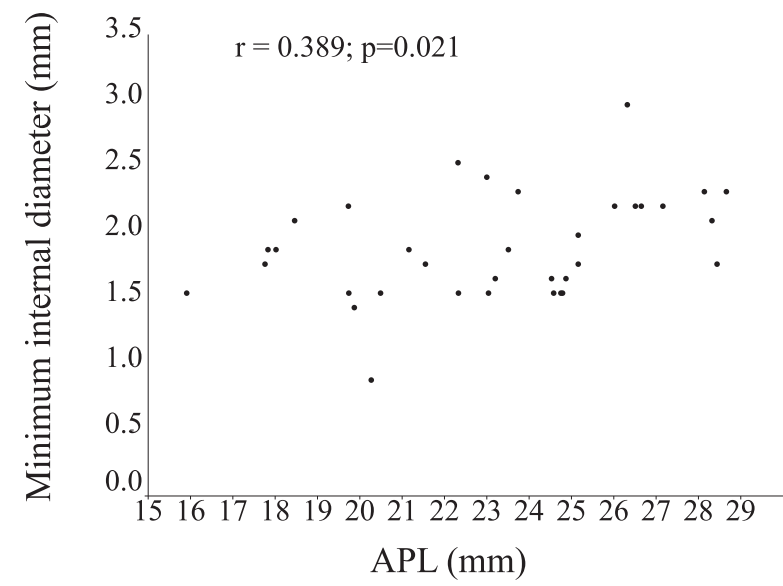

FIGURE 7. Dispersion plot between drill hole minimum inner diameter $(\mathrm{mm})$ and length $(\mathrm{mm})$ of the limpet $N$. magellanica.

$r=0.384 ; p=0.023$; Figure 7). This result suggests that larger predators choose larger prey, although most of the variability is not explained by this relationship (i.e., there are other variables involved).

\section{Site Selectivity}

Drill holes are placed irrespectively of the anterior $(n=20)$ or posterior $(n=19)$ halves of the valves (goodness of fit chi-square test, $p=0.873$ ). Concerning the selection in dorso-ventral direction (upper, middle and lower parts) there are significant differences between observed frequencies and expectations derived from the uniform distribution (the predator drills without regarding the position; goodness of fit chi-square test, $p<0.000$ ). Drill holes are more abundant than expected in the middle sector (U-shaped muscle scar), and less abundant than expected in the lower sector. The upper sector has a similar amount of drilling than the expectation (Figure 8). A similar result was obtained when comparing the middle sector against the other two (goodness of fit chi-square test, $p<0.000$ ). In Appendix 3 a database with information of non drilled specimens used to estimate surface areas of the three sectors of Nacella magellanica shells is provided.

\section{DISCUSSION}

The majority of the drill holes described here belong to Oichnus simplex Bromley, 1981, produced mainly by muricid gastropods (Bromley, 1981). The presence of marks from micro-rasping of multiple elements (Figure 5.4-6) strongly suggests that the holes were drilled by a radula-type tool. Finally, almost all drilled specimens have sin-

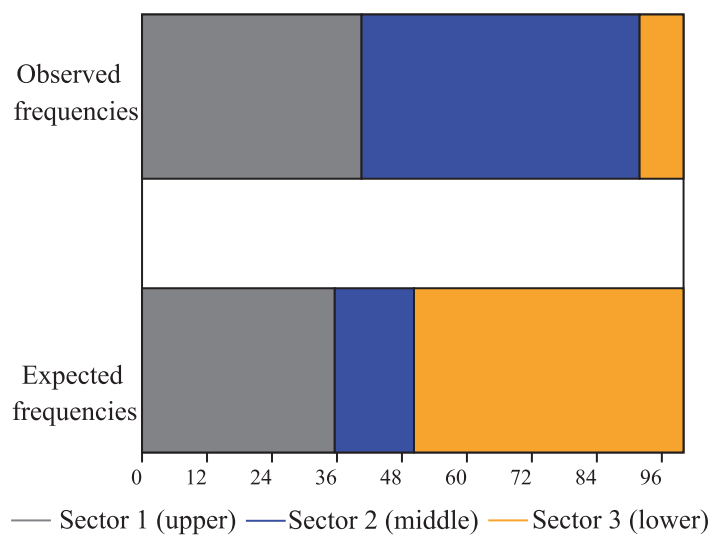

FIGURE 8. Stacked bars with the distribution of observed vs. expected frequencies (uniform distribution) of drill holes in sectors along a dorso ventral direction. Data as percentages.

gle holes, and in the only case of double O. simplex, one is non-functional (Figure 5.2). The abundance of Trophon geversianus in the death assemblages and its dominance over naticids (271 specimens versus 4 of the naticid Notocochlis isabelleana), indicates that limpet drill holes are predatory and were made by this species. This observation is consistent with previously published studies, which show that $T$. geversianus is by far the most dominant boring species on the Atlantic coast of Argentina (Martinelli et al., 2013). Additionally, we observed species selection and marked stereotypy, which provide yet more evidence of the predatory nature of the borings. With respect to the oval holes, their morphology coincides with Oichnus ovalis Bromley, attributed to octopuses. They could have been produced by the intertidal/shallow subtidal small sized octopuses Octopus tehuelchusor Robsoniella fontaniana, since both species are inhabitants of this area. However, $R$. fontaniana is rare and does not seem to bore shelled prey (Ré, 1989; Ibáñez et al., 2009). As a consequence, we consider that $O$. ovalis is most probably produced by $\quad 0$. tehuelchus. The incidence of $O$. ovalis is quantitatively minor but easily identifiable. As in the other ichnospecies, bored limpet shells have a single drilling, with the exception of one specimen, which has two: one complete and one incomplete.

Our analyses show that limpets were preferred by $T$. geversianus only after mussels, which had the highest predation values. Drilling frequencies per mytilid species of the death assemblage (DA sample) studied here ranged from 4\% (Brachidontes rodriguezii) to $17 \%$ (Aulacomya atra), with a 
figure of $6.9 \%$ for the pooled sample of mytilids (Table 1). Averaged DFs (weighted average) of the four species of mytilids reached a value of $10.34 \%$. Both estimates of the incidence of drilling predation on mytilids were above the DF for the whole assemblage $(4.72 \%)$, indicating a preference of $T$. geversianus for these bivalves over the rest of the species, that was confirmed statistically. The selection of mussels over limpets is explained mainly by the mobile nature of the latter: muricids lack the ability to manipulate non-sessile prey. Limpets were less drilled in the sample from the death assemblage: $N$. magallenica had a drilling frequency of $3.97 \%$, Siphonaria lessoni less than $1 \%$ and the fissurellids were not drilled at all. Drilling frequency of the pooled sample of limpets was low: $1.57 \%$. Among limpets, Trophon geversianus consumed Nacella magellanica with a frequency significantly higher than expected (i.e., it chooses this limpet species above others). Limpet (sensu lato) drilling frequencies based on the death assemblage rely on a few drilled specimens (i.e., five $N$. magellanica and two $S$. lessoni), which makes these estimations somewhat uncertain.

For the limpet sample, the drilling frequency was $5.64 \%$. The species which was most preyed upon was $N$. magellanica, with a drilling frequency of $8.48 \%$. The difference between both samples might reflect spatial differences in prey distribution in accordance with the existence of sub-environments within the intertidal/shallow subtidal zone. The higher drilling frequency observed for N. magellanica in the limpet sample is probably associated with a field of boulders where the limpets live in greater quantity and concentration compared with other sectors of the intertidal/shallow subtidal where they are more dispersed on the substrate (Figure 2.3). It must also be noted that the limpet sample's estimation of drilling frequencies is based on a larger sample and is hence a more accurate estimate. Drilling frequency on limpets obtained in this sample is slightly higher than the value of $4 \%$ obtained by Yanes and Tyler (2009) for a death assemblage of limpets on San Juan Island, Washington State (USA), in the northwestern Pacific. Palmer (1988) showed an example of an unusually high rate of predation of the muricid Ocenebra lurida on limpets in Turn Island, also in the San Juan archipielago: the author reported that $55 \%$ of the prey items were limpets. In turn, Visaggi and Kelley (2007) described high DFs in a sample of patellid limpets from West Looe Beach, Cornwall (southwestern England): $31.4 \%$ of the 188 shells had evidence of drilling predation, with a high inci- dence of incomplete borings (34.2\%). Black (1978) studied drilling predation on limpets in Western Australia, in rock outcrops dominated by these gastropods. In his survey, the author found that among the in-vivo drilling observations, 27 out of 128 cases $(21 \%)$ occurred on limpets. This figure is higher than ours: $4.96 \%$ of the drilled specimens from the death assemblage sample were limpets (note that this percentage corresponds to the subsample of drilled specimens). Additionally, $41 \%$ of the limpet shells collected by Black were drilled (179 out of 433), which is a much higher figure than the estimated drilling frequency of Patagonian death assemblages.

Our results suggest that there is a relationship between prey size and predator size, and that larger predators choose larger prey. Similar results were obtained by Yanes and Tyler (2009). Palmer (1988) observed that the soft tissues of limpets are not consumed at random: Ocenebra lurida consumes the gonads first, then the digestive gland and finally, and not always, the foot. Moreover, the author observed that the foot is consumed when the predator is larger than the prey, otherwise predator and prey would detach from the substrate. In this way, prey with a similar energy value, but that can be completely consumed (e.g., mytilids), give the predator more resources for growth. Similar results were described by Black (1978), who found a significant correlation between prey and predator sizes for small species but not in the case of Patelloida alticostata, the largest of the limpet species. Black found a pattern of drilling on the surfaces that cover the gonads and the digestive gland, and interpreted it to mean that consuming the head and foot would put the predator in risk of falling and being dislodged from the prey.

Concerning the selection of the drilling site, we did not find a preference for the anterior or posterior half of the limpet shells. However, Palmer (1988) described a clear, statistically significant preference for the posterior half of Lotia pelta and Tectura scutum when drilled by Ocenebra lurida. Similar results were mentioned by Visaggi and Kelley (2007). Yanes and Tyler (2009) did not check the anterior-posterior preference statistically but their Figure 4 shows an even distribution of holes. Our results coincide with other similar quantitative studies, in that predators chose the upper (apical) part of the shell to bore if compared with the lower sector (Palmer, 1988; Visaggi and Kelley, 2007; Yanes and Tyler, 2009). However, we demonstrated that drillings are particularly concentrated on the middle sector, coinciding with the position of 
the U-shaped muscle scar. This preferential location of the drill holes was mentioned by Visaggi and Kelley (2007). We detected the pattern and gave statistical evidence without previous knowledge of Visaggi and Kelley's abstract. The U-shaped muscle scar runs along the shell parallel to its margin, roughly equidistant from the margin and the apex, except in the anterior end where it follows a different path (Figure 3.2). It is visible only from inside, where it can be seen as a depression, where the shell is thinner. We frequently found limpet shells that were complete but that had lost the external layer above the muscle scar, and we also found these cup-shaped remains alone. We infer that the U-shaped muscle scar is a band of weakness where the predator needs less time to bore, therefore reduces the risk of being exposed during low tides (Black, 1978). It is also possible that chemicals produced by the limpet can diffuse easier through this thinner band, thus giving the predator a signal. The signals that attract predators are endproducts of the metabolic activity of the prey (Carriker and Van Zandt, 1972). In a series of experiments between oysters as prey (Crassostrea virginica) and the muricid gastropod Urosalpinx cinerea as the predator, Carriker and Van Zandt (1972) showed that in some cases the predators drilled closer to the places where these chemicals leave the oysters. The oysters were bound with rubber bands to avoid gaping of valves and pumping (experiment b, Carriker and Van Zandt, 1972). Limpets might release metabolic chemicals through the weaker band of the U-shaped muscle scar and attract predators, which choose that area to drill.

Siphonaria lessoni was eaten by Trophon geversianus in relatively low proportions $(1.03 \%)$ in the death assemblage, which is consistent with previous studies showing that this species is repulsive to a variety of predators, including sea stars, crabs and gastropods, perhaps by the presence of chemical compounds in the mucus and tissues of the foot (McQuaid et al., 1999; Rovirosa and San Martín, 2006; Laitano et al., 2008). However, some muricids, such as Morula fuscula from Singapore, preferably eat pulmonate limpets (Chim and Ong, 2012), showing that in some cases muricids are adapted to taking advantage of this item as food. Another possible or complementary explanation of the reduced consumption of $S$. lessoni is that this species is distributed higher up in the intertidal than the other limpets (Adami, 2008). Last but not least, is must be considered that $S$. lessoni might have been consumed without drilling through the irregu- larities of the shell margin, especially the notch used to exchange gases or the siphonal groove, while feeding out of its home scar.

In the case of Fissurella radiosa and Diodora patagonica, for which only unbored specimens were found, a different anti-predatory strategy can be invoked. In the rocky shores of Chile, experimental studies have shown that Fissurella limbata presents an active escape response to sea star predators (Heliaster helianthus), causing an increase in its foraging activity (Escobar and Navarrete, 2011). We speculate that the Argentinian Patagonian key-hole limpets $F$. radiosa and $D$. patagonica also display a rapid and active escape response to drillers and other potential predators.

In the aforementioned study by Chim and Ong (2012) in Singapore, Morula fusca drilled almost all of the prey species, regardless of whether they were limpets or not. However, two other studies in Japan (Yamamoto, 1993, 2004) showed that limpets consumed by $M$. fusca were rarely drilled. In the first study, none of the limpets (i.e., Siphonaria japonica, Patelloida saccharina and Collisella heroldi) consumed by $M$. fusca were drilled, even though $78 \%$ of littorinids and all the mytilids preyed upon had drill holes (Yamamoto, 1993). In the second study, only a small percentage of limpet prey (i.e., $10 \%$ of Siphonaria japonica, $16 \%$ of Lottia spp. and $27 \%$ of Patelloida saccharina lanx) were drilled. The use of different feeding strategies (drilling or non-drilling) is probably related to differences in handling time. For $M$. fusca in Japan, it is possible that drilling is not the best technique because of its 2 to 3.4 times longer handling time as compared to a non-drilling method (Yamamoto, 2004). However, for the same species in Singapore, it is then possible that drilling is the preferred feeding technique because of its relatively short handling time when consuming limpets, as was observed by Chim and Ong (2012). These authors explain that when not drilling, $M$. fusca gained access to the flesh of limpets by inserting its proboscis through a gap between the substratum and the shell of the prey. However, many Siphonaria species in Singapore attach firmly to their home scars in response to predation, and this probably explains the intensive use of drilling by their muricid predators. As was mentioned before, the vagile nature of limpets (i.e., the lack of fixed attachment such as byssus or cement), makes them a different kind of prey. On the one hand, limpets can escape actively, while on the other, as long as the foot is the only attachment, it cannot be consumed if the predator does not want to be removed from the 
substrate. Besides the muricid M. fusca from Singapore, in the southern tip of South America it has been recognized that the muricid Acanthina monodon also adopts two different strategies, the drilling and non-drilling methods, which vary according to the size and morphology of its mussel prey (Gordillo, 2001; Gordillo and Archuby, 2012). Archuby and Leighton (2014) showed by means of experiments that the muricid Nucella lamellosa is able to kill and consume the barnacle prey Semibalanus cariosus, leaving incomplete drill holes or no drilling at all. These authors proposed that $N$. lamellosa probably has narcotizing saliva that anesthetizes their barnacle prey and causes the aperture to open up passively. In this way, the gastropod stops drilling and leaves an incomplete scar or no mark at all. This hypothesis is supported by the fact that a powerful vasodilator and hypotensive agent has already been isolated from the salivary gland of the muricid Thais haemastoma (Huang and Mir, 1972). However, it must be considered that the anatomy of the barnacle and the limpet do differ significantly, and this probably has a relevant consequence on the predator-prey interaction (e.g., the many plates and sutures of barnacles increase the probability of being reached by these narcotizing substances). In our survey, the ratio of complete to incomplete drill holes in the case of Nacella magellanica differs from the aforementioned example: from 38 limpets drilled only three have incomplete holes, while from 23 barnacles, 21 had incomplete drillings. It could be considered that some incomplete drillings may be due to the presence of a secondary predator that causes the drilling gastropod to abandon its prey. This was documented during experiments with the muricid Nucella lamellosa preying upon the mussel Mytilus trossulus, with and without the presence of a specimen of Cancer gracilis (Chattopadhyay and Baumiller, 2007). The authors demonstrated that in the presence of the crab, there is a higher frequency of incomplete drill holes. Based on the above studies, we conclude that drilling frequencies calculated from fossil or recent death assemblages probably underestimate the relevance of gastropod predation on limpets, given the possibility of alternative ways of feeding without making holes (e.g., Archuby and Leighton, 2014; Gordillo and Archuby, 2012; Hart and Palmer, 1987; Klompmaker et al., 2015).

Drill holes in fossil limpets have never been reported within published literature (Yanes and Tyler, 2009), which is most probably related to the fact that limpets are very rarely preserved in the fossil record. Furthermore, considering the amount of time the different species have resided in the region, one might expect that the postglacial species (e.g., Nacella magellanica and the fissurellids) are more likely to be preyed upon than those which already lived in the ecosystems (e.g., Siphonaria lessoni). However, only one (N. magellanica) was preyed upon, so this does not actually help in understanding the patterns observed.

Evidence from dead shell assemblages can be viewed from the perspective of the optimal foraging theory, although lab and field experiments are needed to corroborate these results. Palmer (1984) has already demonstrated that driller muricoid gastropods (Nucella spp.) in the north eastern Pacific develop behaviors that fit with the expectations of the optimal foraging theory, and has described the difficulties of contrasting the results of lab and field experiments in a highly complex biological system. We found a pattern that suggests the selection of species in favor of mussels when compared to limpets, and in favor of $N$. magellanica with respect to the other species of limpets. Similar results have been published before for different muricid species preying upon different mytilid species in Tierra del Fuego (Gordillo and Archuby, 2012), as well as for Venus (=Ameghinomya) antiqua in central Patagonia (Gordillo and Archuby, 2014). Prey species preference, site and size selection, as well the facultative character of the drilling behavior of $T$. geversianus, should be confirmed through laboratory experiments, which include limpets, in order to understand the importance of the incidence of muricid predation in shallow rocky bottom communities of Patagonia.

\section{FINAL REMARKS}

Recent limpets from death assemblages collected at the high water mark at Puerto Lobos, on the Argentine Patagonian coast, have predatory drill holes belonging to the ichnospecies Oichnus simplex Bromley, 1981. With the use of SEM, we detected Radulichnus-like microtraces on the walls of holes, originating from the physical rasping of the prey shell. The drill holes are produced by muricid gastropods, most probably Trophon geversianus. A few boreholes resemble Oichnus ovalis Bromley, 1983, attributable to octopuses.

The drilling frequency on limpets reached 1.57 $\%$ of the death assemblage. Nacella magellanica was more drilled than other limpet species, with $3.97 \%$. This last figure is lower than the drilling frequency obtained for the whole mollusk assemblage $(4.72 \%)$, thus showing a negative selection of lim- 
pets in comparison with other groups such as mytilids. The drilling frequencies of the Patagonian limpets are low, coinciding with that described in other studies. Limpets are, however, a persistent food item of drilling gastropods. Nevertheless, other studies show high levels of predation of muricids on limpets in different environmental contexts. One possible factor related to the selection of prey other than limpets is their vagile, non-fixed nature in comparison with other sessile rock inhabitants, fixed by byssus or cement: limpets cannot be fully consumed if the predator does not want to fall when the prey detaches from the substrate after death.

Three different kinds of limpets (true, key-hole and pulmonate), although inhabiting similar habitats, show different patterns of drilling predation. All of them are less bored than mytilids. Among the limpets, the highest concentration of drill holes occurs in N. magellanica shells, the most abundant limpet species in the rocky shallow environments of the Patagonian Atlantic coast. T. geversianus selects $N$. magellanica specimens to consume with statistical significance, with respect to the pulmonate Siphonaria lessoni and the key-hole limpets Fissurella radiosa and Diodora patagonica. We speculate that $S$. lessoni is less consumed because of its low palatability and its occurrence in the upper intertidal beyond the reach of predators, while $F$. radiosa and $D$. patagonica are able to escape predators. Thus, prey behavior seems to be a relevant factor which influences predation rates and their traces.

Drill holes were preferentially placed on the apical portion of the shell with respect to the lower part. We found drilling preference on the U-shaped muscle scar, suggesting site selectivity related to a band of shell weakness, probably associated with a place where metabolic chemicals can cross the shell more easily.

Hole diameter correlated positively with limpet size, suggesting that larger predators drill larger prey.
The absence of predatory drill holes in fossil limpet shells remains unexplained. The scarcity of limpets in the fossil record partially explains this phenomenon. Nevertheless, evidence from studies based on living specimens, in the field and in experiments, as well as the study of recent death assemblages, indicates that they will probably be detected with more research.

More work with living Trophon geversianus is needed to evaluate our results in relation to the behavior of predators, as proposed in the foraging theory.

\section{ACKNOWLEDGEMENTS}

The authors are grateful to S. Villa (Universidad Nacional de Río Negro) who helped with processing the samples. I.L. Gliemmo de Archuby (La Plata, Argentina) helped with modeling shells in order to calculate the areas per sector. M. Arce (Instituto de Investigación en Paleobiología y Geología, Universidad Nacional de Río Negro) provided the SEM images. L. Storero (Instituto de Biología Marina y Pesquera Almirante Storni, Universidad Nacional del Comahue) supplied information on the octopus Robsonella fontaniana. D. Chattopadhyay and an anonymous reviewer greatly improved this manuscript with their comments. Finally, the authors wish to thank A. Swartz, a strong defender of open access to academic journals who died in the fight to make them freely available to the public.

\section{FINANCIAL SUPPORT}

This study was supported by the Consejo Nacional de Investigaciones Científicas y Técnicas (CONICET, Ministerio de Ciencia, Tecnología e Innovación Productiva; S.G., grant number PIP 09260). This paper is also a contribution to projects supported by Universidad Nacional de Río Negro (F.A., grant number 40-A-383) and CONICET (S.G., grant number PIP-114-201101-00238).

\section{REFERENCES}

Adami, M.L. 2008. Efectos de la herbivoría de la lapa Siphonaria lessoni Blainville, 1824 (Gastropoda) sobre la comunidad asociada a Brachidontes rodriguezii (d' Orbigny, 1846) (Bivalvia). Revista de Museo Argentino de Ciencias Naturales, 10:309-317. https://doi.org/ 10.22179/revmacn.10.285

Andrade, C. and Ríos, C. 2007. Estudio experimental de los hábitos tróficos de Trophon geversianus (Pallas 1774) (Gastropoda: Muricidae): selección y manipulación de presas. Anales del Instituto de la Patagonia, 35:45-53. 
Archuby, F.M., Adami, M., Martinelli, J.C., Gordillo, S., and Boretto, G.M. 2015. Regional-scale compositional and size fidelity of rocky intertidal communities from the Patagonian Atlantic Coast. Palaios, 30:627-643. http://dx.doi.org/10.2110/palo.2014.054

Archuby, F.M. and Leighton, L.R. 2014. Facultative drilling behavior of Nucella species (Muricidae) upon the thatched barnacle (Semibalanus cariosus) from field and experimental observations: consequences for the fossil record of predation. 4th International Palaeontological Congress Abstract Volume, p. 77

Bazterrica, M.C., Silliman, B.R., Hidalgo, F.J., Crain, C.M., and Bertness, M.D. 2007. Limpet grazing on a physically stressful Patagonian rocky shore. Journal of Experimental Marine Biology and Ecology, 353:22-34. https://doi.org/10.1016/j.jembe.2007.08.018

Black, R. 1978. Tactics of whelks preying on limpets. Marine Biology, 46:157-162. https://doi.org/ 10.1007/BF00391531

Bromley, R.G. 1981. Concepts in ichnotaxonomy illustrated by small round holes in shells. Acta Geologica Hispanica, 16:55-64.

Bromley, R.G. 1993. Predation habits of octopus past and present and a new ichnospecies, Oichnus ovalis. Bulletin of the Geological Society of Denmark, 40:167-173.

Carriker, M.R. and Van Zandt, D. 1972. Predatory behavior of a shell-boring muricid gastropod, p. 157-243. In Winn, H.E. and Olla, B.L. (eds.), Behavior of Marine Animals. Volume I: Invertebrates. Plenum Press, New York.

Ceranka, T. and Złotnik, M. 2003. Traces of cassid snails predation upon the echinoids from the Middle Miocene of Poland. Acta Palaeontologica Polonica, 48:491-496.

Chattopadhyay, D. and Baumiller, T.K. 2007. Drilling under threat: An experimental assessment of the drilling behavior of Nucella lamellosa in the presence of a predator. Journal of Experimental Marine Biology and Ecology, 352:257-266. https://doi.org/10.1016/ j.jembe.2007.08.001

Chattopadhyay, D. and Baumiller, T.K. 2010. Effect of durophagy on drilling predation: a case study of Cenozoic molluscs from North America. Historical Biology, 22:367-379. https:// doi.org/10.1080/08912961003600445

Chattopadhyay, D., Rathie, A., and Das, A., 2013a. The effect of morphology on post-mortem transportation of bivalve and its taphonomic implications. Palaios, 28:203-209. https://doi.org/ 10.2110/palo.2012.p12-103r

Chattopadhyay, D., Rathie, A., Miller, D., and Baumiller, T. K. 2013b. Hydrodynamic effects of drill holes on post-mortem transportation of bivalve shells and its taphonomic implications. Palaios, 28:875-884. https://doi.org/10.2110/palo.2013.029

Chim, C.K. and Ong, Y.Y.B. 2012. Diet of an intertidal predator, Morula fusca (Neogastropoda: Muricidae), on St. John's Island, Singapore. Contributions to Marine Science, 2012:153-158.

Cleland, C.E. 2001. Historical science, experimental science, and the scientific method. Geology, 29:987-990. https://doi.org/10.1130/0091-7613(2001)029<0987:HSESAT>2.0.CO;2

Dadon, J.R. 2005. Changes in the intertidal community structure after a mass mortality event in sandy beaches of Argentina. Contributions to Zoology, 74:27-39.

Daleo, P., Escapa, M., Isacch, J.P., Ribeiro, P., and Iribarne, O. 2005. Trophic facilitation by the oystercatcher Haematopus palliates Temminick on the scavenger snail Buccinanops globulosum Kiener in a Patagonian bay. Journal of Experimental Marine Biology and Ecology, 325:27-34. https://doi.org/10.1016/j.jembe.2005.04.022

De Aranzamendi, M., Bastidas, R., and Gardenal, C. 2011. Different evolutionary histories in two sympatric limpets of the genus Nacella (Patellogastropoda) in the South-western Atlantic coast. Marine Biology, 158:2405-2418. https://doi.org/10.1007/s00227-011-1742-3

Dietl, G.P., Herbert, G.S., and Vermeij, G.J. 2004. Reduced competition and altered feeding behavior among marine snails after a mass extinction. Science, 306(5705):2229-2231. https://doi.org/10.1126/science.1106182

Escobar, J.B. and Navarrete, S.A. 2011. Risk recognition and variability in escape responses among intertidal molluscan grazers to the sun star Heliaster helianthus. Marine Ecology Progress Series, 421:151-161. https://doi.org/10.3354/meps08883

Fiori, S.M. and Cazzaniga, N.J. 1999. Mass mortality of the yellow clam, Mesodesma mactroides (Bivalvia: Mactracea) in Monte Hermoso beach, Argentina. Biological Conservation, 89: 305309. https://doi.org/10.1016/S0006-3207(98)00151-7

Gelós, E., Spagnuolo, J., Schillizzi, R., and Gómez, E. 1994. Textura y mineralogía de los sedimentos de playa entre San Antonio Oeste (Río Negro) y Puerto Lobos (Chubut). Revista de la Asociación Geológica Argentina, 49:85-92. 
Gil, D.G. and Zaixso, H.E. 2008. Feeding ecology of the subantarctic sea star Anasterias minuta within tide pools in Patagonia, Argentina. Revista de Biología Tropical, 56 (Suppl. 3): 311328.

González-Wevar, C.A., Hüne, M., Cañete, J.I., Mansilla, A., Nakano, T., and Poulin, E. 2012. Towards a model of postglacial biogeography in shallow marine species along the Patagonian Province: lessons from the limpet Nacella magellanica (Gmelin, 1791). BMC Evolutionary Biology, 12:139. https://doi.org/10.1186/1471-2148-12-139

Gordillo, S. 1994. Perforaciones en bivalvos subfósiles y actuales del Canal Beagle, Tierra del Fuego. Ameghiniana, 31:177-185.

Gordillo, S. 1998. Trophonid gastropod predation on recent bivalves from the Magellanic Region, p. 251-254. In Johnston, P.A. and Haggart, J.W. (eds.), Bivalves: an Eon of Evolution. Paleobiological Studies Honoring Norman N. Newell. University of Calgary Press, Calgary.

Gordillo, S. 2001. Marcas de la depredación de Acanthina Fischer von Waldheim, 1807 (Gasteropoda: Muricidae) sobre Bivalvia. Ameghiniana, 38(1):55-60.

Gordillo, S. 2013. Cannibalism in Holocene muricid snails in the Beagle Channel, at the extreme southern tip of South America: an opportunistic response? Palaeontologia Electronica, 16(1):1-13. https://doi.org/10.26879/344

Gordillo, S. and Archuby, F.M. 2012. Predation by drilling gastropods and asteroids upon mussels in rocky shallow shores of southernmost South America: paleontological implications. Acta Palaeontologica Polonica, 57:633-643. https://doi.org/10.4202/ app.2010.0116

Gordillo, S. and Archuby, F.M. 2014. Live-live and live-dead interactions in marine death assemblages: the case of the Patagonian clam Venus antiqua. Acta Palaeontologica Polonica, 59:429-442. https://doi.org/10.4202/app.2011.0176

Griffin, M., and Pastorino, G. 2005. The genus Trophon Monfort, 1810 (Gastropoda: Muricidae) in the tertiary of Patagonia. Journal of Paleontology, 79:296-331. https://doi.org/10.1666/00223360(2005)079<0296:TGTMGM>2.0.CO;2

Hammer, Ø., Harper, D.A.T., and Ryan, P.D. 2001. Past: Paleontological Statistics Software Package for Education and Data Analysis. Palaeontologia Electronica, 4.1.4:1-9 https:// palaeo-electronica.org/2001_1/past/issue1_01.htm.

Harper, E.M. 2003. Assessing the importance of drilling predation over the Palaeozoic and Mesozoic. Palaeogeography, Palaeoclimatology, Palaeoecology, 201(3-4):185:198. https:// doi.org/10.1016/S0031-0182(03)00624-2

Harper, E.M. 2002. Plio-Pleistocene octopod drilling behavior in scallops from Florida. Palaios, $17: 292-296$.

https://doi.org/10.1669/0883-1351(2002)017<0292:PPODBI>2.0.CO;2

Hart, M.W. and Palmer, A.R. 1987. Stereotipy, ontogeny, and heritability of drill site selection in thaidid gastropods. Journal of Experimental Marine Biology and Ecology, 107:101-120. https://doi.org/10.1016/0022-0981(87)90189-4

Hidalgo, F.J., Silliman, B.R., Bazterrica, M.C., and Bertness, M.D. 2007. Predation on the rocky shores of Patagonia, Argentina. Estuaries and Coasts, 30(5):887-895. https://doi.org/ 10.1007/BF02841342

Huang, C.L. and Mir, G.N. 1972. Pharmacological investigation of salivary gland of Thais haemastoma (Clench). Toxicon, 10(2):111-117. https://doi.org/10.1016/0041-0101(72)902590

Ibáñez, C.M., Sepúlveda, R.D., Guerrero, J., and Chong, J. 2008. Redescription of Robsonella fontaniana (Cephalopoda: Octopodidae). Journal of the Marine Biological Association of the UK, 88(3):617-624. https://doi.org/10.1017/S002531540800101X

Ibáñez, C.M., Sepúlveda, R.D., Sanhueza, E., Ruiz, J.F., and Chong, J. 2009. Estrategias de forrajeo de Robsonella fontaniana (d'Orbigny, 1834) (Cephalopoda: Octopodidae). Revista de Biologia Marina y Oceanografia, 44(2):277-283. https://doi.org/10.4067/S071819572009000200002

Iribarne, O. 1991. Life history and distribution of the small south western Atlantic octopus, Octopus tehuelchus. Journal of Zoology, 223:549-568. https://doi.org/10.1111/j.14697998.1991.tb04387.x

Iribarne, O., Fernandez, M., Díaz, M., and Clemente, M. 1993. Prey attack by the Patagonian octopus Octopus tehuelchus d'Orbigny: an odd pattern. The Veliger, 36(2):199-202. 
Iribarne, O., Fernandez, M., and Zucchini, H. 1991. Prey selection by the small Patagonian octopus, Octopus tehuelchus d'Orbigny. Journal of Experimental Marine Biology and Ecology, 148:271-281. https://doi.org/10.1016/0022-0981(91)90087-d

Kabat, A.R. 1990. Predatory ecology of naticid gastropods with a review of shell boring predation. Malacologia, 32:155-193.

Kelley, P.H. and Hansen, T.A. 2003. The fossil record of drilling predation on bivalves and gastropods, p. 113-139. In Kelley, P.H., Kowalewski, M., and Hansen T.A. (eds.), PredatorPrey Interactions in the Fossil Record. Kluwer Academic/Plenum Publishers, New York.

Kelley, P.H. and Hansen, T.A. 2007. Latitudinal patterns in naticid gastropod predation along the east coast of the United States: A modern baseline for interpreting temporal patterns in the fossil record, p. 287-299. In Sediment-organism Interactions: A Multifaceted Ichnology. SPEM Special Publication, No. 88.

Kidwell, S.M. and Tomašových, A. 2013. Implications of time-averaged death assemblages for ecology and conservation biology. Annual Review of Ecology, Evolution, and Systematics, 44(1):539-563. https://doi.org/10.1146/annurev-ecolsys-110512-135838

Klompmaker, A.A. and Kelley, P.H. 2015. Shell ornamentation as a likely exaptation: evidence from predatory drilling on Cenozoic bivalves. Paleobiology, 41(01):187-201. https://doi.org/ 10.1017/pab.2014.12

Klompmaker, A.A., Portell, R.W., Lad, S.E., and Kowalewski, M. 2015. The fossil record of drilling predation on barnacles. Palaeogeography, Palaeoclimatology, Palaeoecology, 426: 95-111. http://dx.doi.org/10.1016/j.palaeo.2015.02.035

Kowalewski, M. 2002. The fossil record of predation: an overview of analytical methods, p. 3-42. In Kowalewski, M. and Kelley, P.H. (eds.), The Fossil Record of Predation. Paleontological Society Special Papers, Pittsburg.

Kowalewski, M. 2004. Drill holes produced by the predatory gastropod Nucella lamellosa (Muricidae): palaeobiological and ecological implications. Journal of Molluscan Studies, 70(4):359-370. https://doi.org/10.1093/mollus/70.4.359

Kowalewski, M. and Leighton, L.R. 2007. Predator-prey interactions: experimental and field approaches. Journal of Shellfish Research, 26:217-220. https://doi.org/10.2983/07308000(2007)26[217:pieafa]2.0.co;2

Kowalewski, M., Dulai, A., and Fürsich, F.T. 1998. A fossil record full of holes: the Phanerozoic history of drilling predation. Geology, 26:1091-1094. https://doi.org/10.1130/00917613(1998)026<1091:AFRFOH>2.3.CO;2

Laitano, M.V., Nuñez, J.D., and Cledón, M. 2008. Efectividad de estrategias de defensa contra la depredación de dos moluscos del intermareal rocoso de Argentina. VII Congreso Latinoamericano de Malacología. Valdivia. Resúmenes, p. 99.

Leighton, L. R. 2003. Morphological response of prey to drilling predation in the Middle Devonian. Palaeogeography, Palaeoclimatology, Palaeoecology, 201(3-4):221-234. https:// doi.org/10.1016/S0031-0182(03)00627-8

Leighton, L.R. and Aronowsky, A. 2003. Exciting research on boring predation. Palaeogeography, Palaeoclimatology, Palaeoecology, 201(3-4):183-184. https://doi.org/ 10.1016/S0031-0182(03)00623-0

Lever, J., Kessler, A., Van Overbeeke, A.P., and Thijssen, R. 1961. Quantitative Beach Research II. The «Hole Effect». Netherlands Journal of Sea Research, 1: 339-358. https://doi.org/ 10.1016/0077-7579(61)90008-4

Lopes, R.P. and Simone, L.R.L. 2012. New fossil records of Pleistocene marine mollusks in Southern Brazil. Revista Brasileira de Paleontologia, 15(1):49-56. https://doi.org/10.4072/ rbp.2012.1.04

López, R.A., Penchaszadeh, P.E., and Marcomini, S.C. 2008. Storm-related strandings of mollusks on the northeast coast of Buenos Aires, Argentina. Journal of Coastal Research, 244:925-935. https://doi.org/10.2112/05-0621.1

Lowell, R.B. 1986. Crab predation on limpets: predator behavior and defense features of the shell morphology of prey. Biological Bulletin, 171(3):57-596. https://doi.org/10.2307/1541625

Martinelli, J., Gordillo, S., and Archuby, F.M. 2013. Muricid drilling predation at high latitudes: insights from the Southernmost Atlantic. Palaios, 28:33-41. https://doi.org/10.2110/ palo.2012.p12-087r

McLean, J.H. 1984. Systematics of Fissurella in the Peruviana and Magellanic faunal provinces (Gastropoda: Prosobranquia). Natural History Museum of Los Angeles County, Contributions in Science, 354:1-70. 
McQuaid, C.D., Cretchley, R., and Rayner, J.L. 1999. Chemical defense of the intertidal pulmonate limpet, Siphonaria capensis (Quoy and Gaimard) against natural predators. Journal of Experimental Marine Biology and Ecology, 237:141:154. https://doi.org/10.1016/ s0022-0981(99)00011-8

Morriconi, E. 1999. Reproductive biology of the limpet Nacella (P.) deaurata (Gmelin, 1791) in Bahía Lapataia (Beagle Channel). Scientia Marina, 63:417-426. https://doi.org/10.3989/ scimar.1999.63s1417

Nuñez, J.D., Laitano, M.V., and Cledón, M. 2012. An intertidal limpet species as a bioindicator: Pollution effects reflected by shell characteristics. Ecological indicators, 14:178-183. https:// doi.org/10.1016/j.ecolind.2011.07.015

Olivares-Paz A. 2007. Sistemática molecular del género Fissurella en el Pacífico Sudoriental. Unpublished PhD Thesis, Facultad de Biología, Universidad de Santiago de Compostela, Santiago de Compostela, Spain.

Olivares-Paz, A., Quinteiro, J., and Rey-Méndez, M. 2011. Filogenia molecular de las especies del subgénero Fissurella (Mollusca: Vetigastropoda) de la costa chilena. Revista de Biología Marina y Oceanografía, 46(3):339-348. http://dx.doi.org/10.4067/S071819572011000300005

Pacheco, C.J. and Castilla, J.C. 2001. Foraging behavior of the American oystercatcher Haematopus palliatus pitanay (Murphy 1925) on the intertidal ascidian Pyura praeputialis (Heller 1878) in the Bay of Antofagasta, Chile. Journal of Ethology, 19:23-26. http:// dx.doi.org/10.1007/s101640170013

Paine, R.T. 1966. Food web complexity and species diversity. The American Naturalist, 100: 6575. https://doi.org/10.1086/282400

Palmer, A.R. 1980. A comparative and experimental study of feeding and growth in thaidid gastropods. Unpublished PhD Thesis, University of Washington, USA.

Palmer, A.R. 1984. Prey selection by thaidid gastropods: some observational and experimental field tests of foraging models. Oecologia, 62:162-172. https://doi.org/10.1007/bf00379009

Palmer, A.R. 1988. Feeding biology of Ocenebra lurida (Prosobranchia: Muricacea): diet, predator-prey size relations, and attack behavior. The Veliger, 31(3/4): 192-203.

Pio, M.J. 2010. Anatomía e histología de glándulas pedales asociadas a la estrategia alimenticia del gasterópodo Trophon geversianus (Mollusca: Muricidae). Unpublished Licenciate Thesis, Universidad CAECE, Argentina.

Powell, A. 1973. The patellid limpets of the world (Patellidae), p. 75-206. In Abbott, R.T. (ed.), Indo-Pacific Mollusca. 3rd edition. The Department of Mollusks, Greenville.

R Core Team. 2015. R: A Language and Environment for Statistical Computing. R Foundation for Statistical Computing, Vienna, Austria. http://www.R-project.org.

Ré, M.E. 1989. Estudios ecológicos sobre el crecimiento y la alimentación de Octopus tehuelchus d'Orbigny en Puerto Lobos, Golfo de San Matías. Unpublished PhD Thesis. Universidad Nacional de La Plata, Argentina.

Rovirosa, J. and San Martín, A. 2006. A novel metabolite from the chilean mollusk Siphonaria lessoni. Química Nova, 29:(1), 52-53. https://doi.org/10.1590/s0100-40422006000100011

Roy, K. 1996. The roles of mass extinction and biotic interaction in large-scale replacements: a reexamination using the fossil record of stromboidean gastropods. Paleobiology, 22:436-453. https://doi.org/10.1017/S0094837300016389

Scarabino, V. 1984. Clave para el reconocimiento de moluscos litorales del Uruguay, I. Gastropoda. Contribuciones del Departamento de Oceanografía (Facultad de Humanidades y Ciencias), 1(2):12-22. Montevideo

Schiffbauer, J.D., Yanes, Y., Tyler, C.L., Kowalewski, M., and Leighton, L. R. 2008. The microstructural record of predation: a new approach for identifying predatory drill holes. Palaios, 23(12), 810-820. https://doi.org/10.2110/palo.2008.p08-045r

Tablado, A. and López Gappa, J. 2001. Morphometric diversity of the pulmonate limpet Siphonaria lessoni in different coastal environments. Scientia Marina, 65(1):33-41. https:// doi.org/10.3989/scimar.2001.65n133

Taylor, J.D., Cleevely, R.J and Morris, N.J. 1983. Predatory gastropods and their activities in the Blackdown Greensand (Albian) of England. Palaeontology, 26(3):521-553.

Tomašových, A. and Kidwell, S.M. 2009. Fidelity of variation in species composition and diversity partitioning by death assemblages: time-averaging transfers diversity from beta to alpha levels. Paleobiology, 35(1):94-118. https://doi.org/10.1666/08024.1 
Tomašových, A. and Kidwell, S.M. 2010. Predicting the effects of increasing temporal scale on species composition, diversity, and rank-abundance distributions. Paleobiology, 36(4):672695. https://doi.org/10.1666/08092.1

Tomašových, A. and Kidwell, S.M. 2011. Accounting for the effects of biological variability and temporal autocorrelation in assessing the preservation of species abundance. Paleobiology, 37(2):332-354. https://doi.org/10.1666/09506.1

Tyler, C.L. and Schiffbauer, J.D. 2012. The fidelity of microstructural drilling predation traces to gastropod radula norphology: paleoecological applications. Palaios, $\quad$ 27(9):658-666. https://doi.org/10.2110/palo.2012.p12-014r

Tyler, C.L., Leighton, L.R., and Kowalewski, M. 2014. The effects of limpet morphology on predation by adult cancrid crabs. Journal of Experimental Marine Biology and Ecology 451: 9-15. https://doi.org/10.1016/j.jembe.2013.10.022

Valdovinos, C. and Rüth, M. 2005. Nacellidae limpets of southern South America: taxonomy and distribution. Revista Chilena de Historia Natural, 78:497-517. https://doi.org/10.4067/s0716078x2005000300011

Vermeij, G.J. 1977. The Mesozoic marine revolution: evidence from snails, predators and grazers. Paleobiology, 3:245-258. https://doi.org/10.1017/s0094837300005352

Vermeij, G.J. 1987. Evolution and Escalation: An Ecological istory of LHife. Princeton University Press, Princeton.

Visaggi, C.C. and Kelley, P.H. 2007. Relationship between drilling predation and shell morphology of patellid limpets from Southwestern England. In Proceedings of the GSA Annual Meeting, Session 198, Abstract 13, p. 19813. Denver, Colorado, USA.

Visaggi, C.C. and Kelley, P.H. 2015. Equatorward increase in naticid gastropod drilling predation on infaunal bivalves from Brazil with paleontological implications. Palaeogeography, Palaeoclimatology, Palaeoecology. 438:285-299. https://doi.org/10.1016/ j.palaeo.2015.07.045.

Warwick, R.M. and Light, J. 2002. Death assemblages of molluscs on St Martin's Flats, Isles of Scilly: a surrogate for regional biodiversity? Biodiversity and Conservation, 11:99-112. https://doi.org/10.1023/a:1014094829984

Woods, R.W. 2014. Conservation assessment of the Blackish Oystercatcher Haematopus ater. International Wader Studies, 20:109-115.

Yamamoto, T. 1993. Foraging rhythm of the whelk Muricodrupa fusca (Küster) (Muricidae) in intertidal rockpools. Benthos Research, 45:43-48. https://doi.org/10.5179/ benthos1990.1993.45_43

Yamamoto, T. 2004. Prey composition and prey selectivity of an intertidal generalist predator, Muricodrupa fusca (Küster) (Muricidae). Marine Ecology, 25:35-49. https://doi.org/10.1111/ j.1439-0485.2004.00012.x

Yanes, Y. and Tyler, C.L. 2009. Drilling predation intensity and feeding preferences by Nucella (Muricidae) on limpets inferred from a dead-shell assemblage. Palaios, 24:280-289. https:// doi.org/10.2110/palo.2008.p08-074r

Yorio, P., Tagliorette, A., Harris, G., and Giaccardi, M. 1998. Áreas protegidas costeras de la patagonia: síntesis de información, diagnosis, sobre su estado actual de protección y recomendaciones preliminares. Informes técnicos del plan de manejo integrado de la zona costera patagónica, 39. Fundación Patagonia Natural, Puerto Madryn, Argentina.

Zar, J.H. 2010. Biostatistical Analysis, 5th ed. Pearson Prentice Hall, New Jersey, USA. 


\section{APPENDIX 1.}

Database of species abundances of the mollusk death assemblage from Puerto Lobos, northern Argentine Patagonia. The amount of bored shells and drilling frequencies are provided.

$\begin{array}{lllll}\text { Family } & \text { Species } & \text { Counts } & \text { Bored shells \% drillin } \\ \text { Fissurellidae } & \text { Diodora patagonica } & 3 & 0 & 0.00 \\ \text { Fissurellidae } & \text { Fissurela radiosa } & 74 & 0 & 0.00 \\ \text { Patellidae } & \text { Nacella magellanica } & 126 & 5 & 3.97 \\ \text { Trochidae } & \text { Tegula patagonica } & 241 & 2 & 0.83 \\ \text { Calyptraeidae } & \text { Crepidula dilatata } & 27 & 0 & 0.00 \\ \text { Calyptraeidae } & \text { Crepidula aculeata } & 3 & 0 & 0.00 \\ \text { Calyptraeidae } & \text { Crepidula protea } & 2 & 0 & 0.00 \\ \text { Naticidae } & \text { Notocochlis isabellana } & 4 & 0 & 0.00 \\ \text { Epitoniidae } & \text { Epitonium geogettina } & 4 & 0 & 0.00 \\ \text { Epitoniidae } & \text { Epitonium tenuistriatum } & 1 & 0 & 0.00 \\ \text { Muricidae } & \text { Trophon geversianus } & 271 & 0 & 0.00 \\ \text { Nassariidae } & \text { Buccinanops globulosum } & 40 & 0 & 0.00 \\ \text { Olividae } & \text { Olivancillaria carcellesi } & 2 & 0 & 0.00 \\ \text { Olividae } & \text { Olivella tehuelcha } & 2 & 0 & 0.00 \\ \text { Siphonariidae } & \text { Siphonaria lessoni } & 242 & 2 & 0.83 \\ \text { Mytlilidae } & \text { Mytilus platensis } & 197 & 18 & 9.14 \\ \text { Mytlilidae } & \text { Brachidontes rodriguezi } & 437 & 46 & 10.53 \\ \text { Mytlilidae } & \text { Brachidontes purpuratus } & 1160 & 47 & 4.05 \\ \text { Mytlilidae } & \text { Aulacomya atra } & 119 & 21 & 17.65 \\ \text { Mytlilidae } & \text { Musculus viator } & 1 & 0 & 0.00 \\ \text { Pectinidae } & \text { Aequipecten tehuelchus } & 1 & 0 & 0.00 \\ \text { Anomiidae } & \text { Pododesmus rudis } & 1 & 0 & 0.00 \\ \text { Ungulinidae } & \text { Diplodonta patagonica } & 2 & 0 & 0.00 \\ \text { Veneridae } & \text { Venus antiqua } & 25 & 0 & 0.00 \\ \text { Semelidae } & \text { Semele proficua } & 4 & 0 & 0.00 \\ \text { Hiatellidae } & \text { Panopea abbreviata } & 1 & 0 & 0.00 \\ & & & & \end{array}$




\section{APPENDIX 2.}

Database of drilled specimens of the limpet sample. Integrity: 0: poorly preserved, an important part of the shell is lost (excluded from this database). 1: Well preserved but some minor part of the shell is lost. 2: Well preserved, complete. APL: anterior posterior length. Sectors: 1: upper; 2: middle or U-shaped muscle scar; 3: lower. DIMa: internal maximum diameter (mm). DIMa: internal minimum diameter ( $\mathrm{mm})$. NA: information not available.

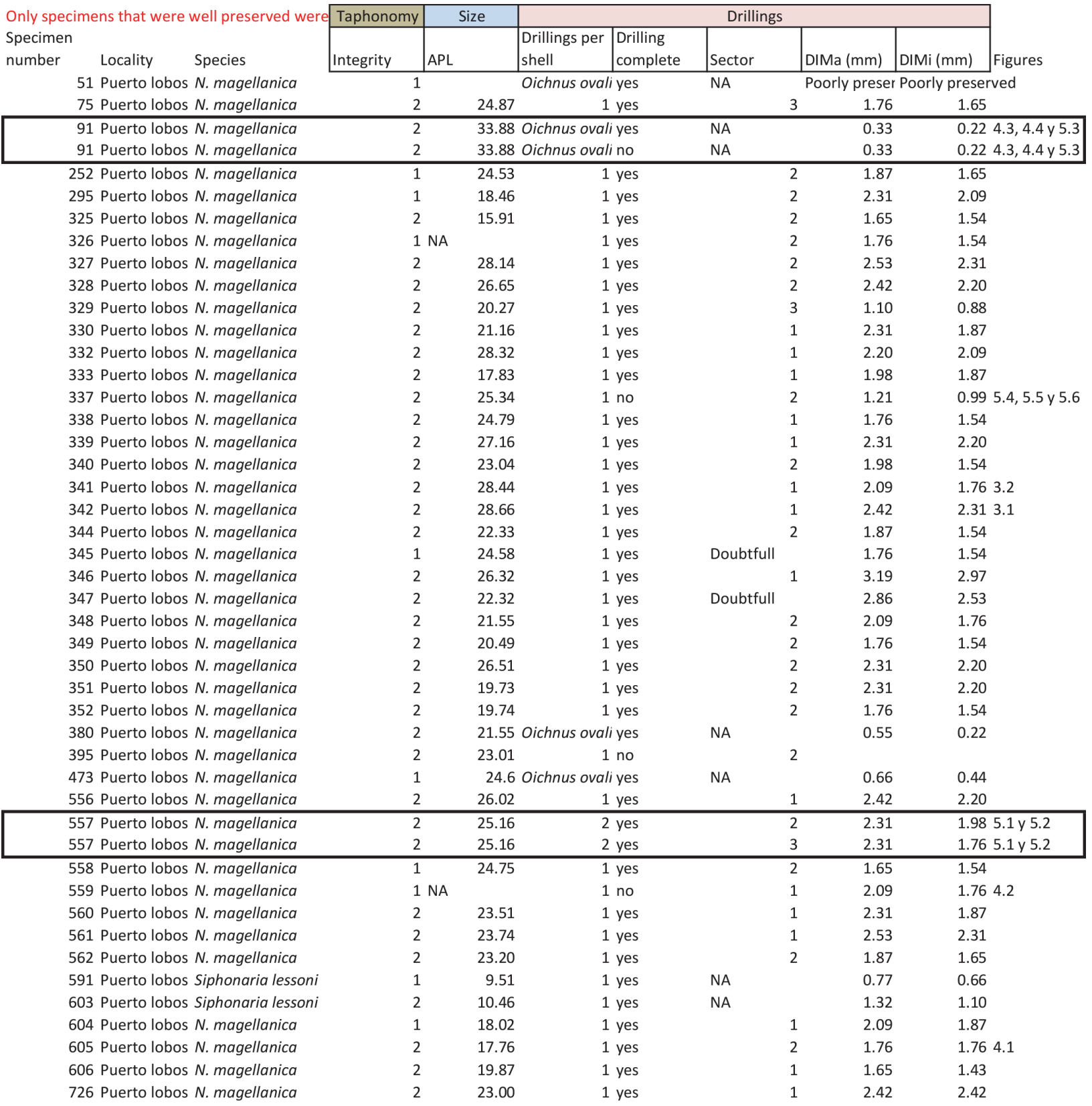




\section{APPENDIX 3.}

Database with information of non drilled specimens used to estimate surface areas of the three sectors of Nacella magellanica shells. Sectors: 1: upper; 2: middle or U-shaped muscle scar; 3 : lower. All measurements in $\mathrm{mm}$ and square $\mathrm{mm}$.

\begin{tabular}{|c|c|c|c|c|c|c|c|c|}
\hline \multirow[b]{2}{*}{ Specimen } & & \multicolumn{4}{|c|}{ Suface per sector } & \multicolumn{3}{|c|}{ Percentages of surface per sector } \\
\hline & APL & $\begin{array}{l}\text { Total } \\
\text { surface }\end{array}$ & 1 & 2 & 3 & $\%$ sector 1 & $\%$ sector 2 & $\%$ sector 3 \\
\hline 1 & 28.02 & 945.41 & 402.63 & 100.12 & 442.66 & 43 & 11 & 47 \\
\hline 3 & 24.28 & 702.52 & 318.11 & 96.00 & 288.41 & 45 & 14 & 41 \\
\hline 6 & 29.27 & 962.76 & 333.27 & 128.48 & 501.01 & 35 & 13 & 52 \\
\hline 7 & 28.03 & 968.65 & 372.11 & 166.48 & 430.06 & 38 & 17 & 44 \\
\hline 12 & 27.02 & 811.93 & 222.11 & 119.10 & 470.72 & 27 & 15 & 58 \\
\hline 14 & 20.43 & 479.45 & 149.30 & 84.46 & 245.69 & 31 & 18 & 51 \\
\hline 15 & 34.52 & 1422.83 & 441.37 & 213.17 & 768.29 & 31 & 15 & 54 \\
\hline 16 & 26.11 & 736.19 & 218.28 & 111.38 & 406.54 & 30 & 15 & 55 \\
\hline 17 & 27.26 & 820.86 & 293.48 & 137.76 & 389.62 & 36 & 17 & 47 \\
\hline 18 & 29.63 & 1061.17 & 368.71 & 137.49 & 554.97 & 35 & 13 & 52 \\
\hline 22 & 22.33 & 665.39 & 295.64 & 98.22 & 271.54 & 44 & 15 & 41 \\
\hline 24 & 25.85 & 809.67 & 292.75 & 72.04 & 444.87 & 36 & 9 & 55 \\
\hline 25 & 23.94 & 662.97 & 264.18 & 103.26 & 295.54 & 40 & 16 & 45 \\
\hline 27 & 28.38 & 999.47 & 304.01 & 144.63 & 550.83 & 30 & 14 & 55 \\
\hline 29 & 27 & 853.32 & 257.48 & 132.12 & 463.73 & 30 & 15 & 54 \\
\hline 28 & 22.46 & 617.05 & 223.39 & 106.85 & 286.81 & 36 & 17 & 46 \\
\hline 30 & 24.21 & 673.49 & 154.73 & 117.38 & 401.38 & 23 & 17 & 60 \\
\hline 31 & 25.84 & 745.22 & 236.34 & 108.07 & 400.81 & 32 & 15 & 54 \\
\hline 32 & 22.24 & 615.20 & 243.78 & 81.08 & 290.34 & 40 & 13 & 47 \\
\hline 33 & 23.32 & 673.28 & 239.57 & 116.67 & 317.04 & 36 & 17 & 47 \\
\hline 34 & 22.43 & 596.14 & 191.58 & 80.91 & 323.65 & 32 & 14 & 54 \\
\hline 36 & 21.13 & 503.84 & 196.81 & 53.93 & 253.10 & 39 & 11 & 50 \\
\hline 38 & 18.1 & 396.90 & 158.48 & 56.25 & 182.18 & 40 & 14 & 46 \\
\hline 39 & 16.18 & 301.43 & 126.20 & 46.42 & 128.81 & 42 & 15 & 43 \\
\hline 40 & 23.19 & 595.58 & 266.00 & 65.21 & 264.37 & 45 & 11 & 44 \\
\hline 43 & 24.24 & 681.18 & 233.34 & 135.18 & 312.65 & 34 & 20 & 46 \\
\hline 45 & 24.83 & 707.90 & 248.76 & 123.20 & 335.94 & 35 & 17 & 47 \\
\hline 48 & 22.19 & 610.33 & 223.55 & 68.52 & 318.26 & 37 & 11 & 52 \\
\hline 52 & 22.2 & 541.56 & 185.66 & 83.46 & 272.43 & 34 & 15 & 50 \\
\hline 58 & 19.32 & 420.62 & 152.29 & 56.12 & 212.20 & 36 & 13 & 50 \\
\hline 606 & 19.93 & 439.85 & 141.91 & 60.41 & 237.54 & 32 & 14 & 54 \\
\hline
\end{tabular}

